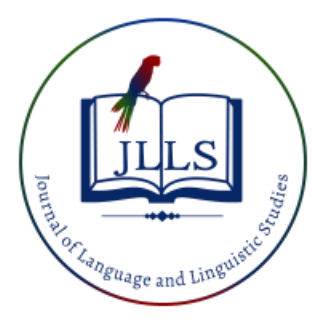

Available online at www.jlls.org

JOURNAL OF LANGUAGE AND LINGUISTIC STUDIES

ISSN: 1305-578X

Journal of Language and Linguistic Studies, 16(4), 2130-2162; 2020

\title{
An autosegmental analysis of the derivation of weak active participles from triconsonantal verbs in modern standard Arabic
}

\author{
Eman Ali a 1 , Radwan Salim Mahadin b \\ a University of Jordan, Amman, Jordan \\ $b$ University of Jordan, Amman, Jordan
}

\section{APA Citation:}

Ali, E. \& Mahadin, R. (2020). An autosegmental analysis of the derivation of weak active participles from triconsonantal verbs in modern standard Arabic. Journal of Language and Linguistic Studies, 16(4), 2130-2162.

Submission Date: 26/6/2020

Acceptance Date:25/8/2020

\begin{abstract}
This study aims to analyze the derivation of weak active participles (APs) from triconsonantal imperfective verbs within the X-slot model of autosegmental phonology. The first stage of the research involves building a corpus of APs from a well-established corpus-based dictionary, namely $m u^{c} d z a m$ ?alluyah ?alcarabijjah ?almuca: sirah $^{2}$ 'Dictionary of Modern Arabic Language'. The corpus contains 620 APs which are categorized, in accordance with the position of the glide in their stems, into initially, medially, finally and doubly weak APs. The analysis reveals that despite having irregular surface representations, the underlying representations of weak APs are parallel to those of their strong counterparts. The surface irregularities of these APs are attributable to the inherent instability of the glides which causes them to be susceptible to diverse phonological rules. These phonological rules are given accurate and simple representations in autosegmental phonology due to the autonomy that elements on different tiers have in this approach.
\end{abstract}

(C) 2020 JLLS and the Authors - Published by JLLS.

Keywords: Autosegmental phonology; MSA; corpus-study; weak stems; APs

\section{Introduction}

Arabic is a Semitic language that has a rich literary heritage dating back to the pre-Islamic period. In addition to Arabic, other major members of the Semitic language family include Aramaic, Ugaritic, Hebrew, Ethiopian, Amharic, Phoenician, Akkadian and Eblaite (Hetzron, 1992). Semitic languages share common phonological, morphological, and syntactic features (Watson, 2002). In terms of phonology, these languages generally employ a limited number of vowels and a wide number of consonants and their consonantal systems incorporate a rich inventory of gutturals, emphatics and geminates. Semitic languages are further marked by their root-and-pattern morphology in which the roots are semantic abstractions embodied by a set of consonants that are inserted into templatic patterns to indicate derivational and inflectional aspects. The distinguishing syntactic features of Semitic

\footnotetext{
1 Corresponding author.

E-mail address: emanawniali@gmail.com
} 
languages include the common usage of VSO (verb-subject-object) word order and the tendency of qualifiers to follow their qualified terms (e.g. adjectives follow the nouns they qualify).

Modern Standard Arabic (MSA) is argued to be a direct descendant of Classical Arabic (CA), i.e. the language of Quran. The emergence of MSA is attributed to the exposure to Western civilization and to the spread of literacy and education. A distinction between the two variants of Standard Arabic, viz. CA and MSA, is commonly made by linguists. The former is a literary form of Arabic used in the Quran and in the pre and early Islamic eras, whereas the latter is the form utilized in formal language contexts in contemporary Arab world. Even though the lexis and stylistics of MSA are different from those of CA, the two variants are largely similar in terms of phonology, morphology and syntax. In addition to the two standardized variants of Arabic, various regional vernaculars of Arabic are used in informal speech contexts. Examples of Arabic regional vernaculars include Jordanian Arabic, Palestinian Arabic and Iraqi Arabic. Table 1 presents the consonantal inventory of MSA:

Table 1. MSA Consonantal Inventory

\begin{tabular}{|c|c|c|c|c|c|}
\hline $\mathrm{b}$ & Voiced bilabial stop & $\mathrm{s}$ & $\begin{array}{l}\text { Voiceless dental-alveolar } \\
\text { fricative }\end{array}$ & $\mathrm{k}$ & Voiceless velar plosive \\
\hline $\mathrm{m}$ & Voiced bilabial nasal & $\mathrm{z}$ & Voiced dental-alveolar fricative & $\mathrm{x}$ & $\begin{array}{l}\text { Voiceless uvular } \\
\text { fricative }\end{array}$ \\
\hline $\mathrm{f}$ & Voiceless labiodental fricative & $\underline{\mathrm{t}}$ & $\begin{array}{l}\text { Voiceless emphatic dental- } \\
\text { alveolar plosive }\end{array}$ & $\gamma$ & Voiced uvular fricative \\
\hline $\mathrm{j}$ & Voiced palatal glide & $\underline{\mathrm{d}}$ & $\begin{array}{l}\text { Voiced emphatic dental-alveolar } \\
\text { plosive }\end{array}$ & $q$ & Voiceless uvular stop \\
\hline $\mathrm{w}$ & Voiced labiovelar glide & $\underline{\mathrm{S}}$ & $\begin{array}{l}\text { Voiceless emphatic dental- } \\
\text { alveolar fricative }\end{array}$ & $\underline{\mathrm{h}}$ & $\begin{array}{l}\text { Voiceless pharyngeal } \\
\text { fricative }\end{array}$ \\
\hline$\theta$ & Voiceless interdental fricative & $\underline{\partial}$ & $\begin{array}{l}\text { Voiced emphatic interdental } \\
\text { fricative }\end{array}$ & c & $\begin{array}{l}\text { Voiced pharyngeal } \\
\text { fricative }\end{array}$ \\
\hline д & Voiced interdental fricative & $\mathrm{r}$ & Voiced dental-alveolar tap & ? & Voiceless glottal stop \\
\hline $\mathrm{t}$ & Voiceless dental-alveolar stop & 1 & Voiced dental-alveolar lateral & $\mathrm{h}$ & $\begin{array}{l}\text { Voiceless glottal } \\
\text { fricative }\end{array}$ \\
\hline $\mathrm{d}$ & Voiced dental-alveolar stop & $\int$ & Voiceless postalveolar fricative & & \\
\hline $\mathrm{n}$ & Voiced dental-alveolar nasal & $d_{3}$ & Voiced postalveolar affricate & & \\
\hline
\end{tabular}

As can be noticed from Table 1, MSA, as a member of the Semitic family, employs a set of glottal $(\mathrm{P}, \mathrm{h})$, pharyngeal $\left(\underline{\mathrm{h}},{ }^{\mathrm{c}}\right)$ and uvular $(\mathrm{x}, \mathrm{\gamma})$ consonants. These consonants are grouped under one category labelled gutturals. Gutturals are consonants produced with "a primary constriction in the posterior region of the vocal tract" (McCarthy, 1994). The phonemic inventory of MSA also has a class of consonants whose production involves a primary constriction in the interior region of the vocal tract, or the oral cavity, accompanied by a secondary retraction of the tongue towards to the posterior region of the vocal tract, or the pharyngeal cavity. This class is referred to as emphatics and it includes four phonemes $/ \underline{t}, \underline{\mathrm{d}}$, $\underline{\mathrm{s}}, \underline{\partial} /$ which contrast with their non-emphatic counterparts /t, d, s, ð/ (e.g. ti:n 'figs' and ti:n 'mud'). Contrary to the rich consonantal inventory of MSA, the vocalic inventory of this variety of Arabic only contains three short vowels as shown in Table 2. 
Table 2. MSA Short Vowels

\begin{tabular}{cl}
\hline $\mathrm{i}$ & high front unrounded \\
$\mathrm{a}$ & low central unrounded \\
$\mathrm{u}$ & high back rounded
\end{tabular}

Each of these three short vowels has a long counterpart. However, it is argued that even though long vowels have phonetic realizations, these vowels are not present on the underlying level of representation. Rather, a long vowel is composed of a sequence of a short vowel and a glide in the underlying representation. This sequence is changed to a long vowel through application of certain phonological processes such as syllabicity assimilation (e.g. /ij/ $\rightarrow / \mathrm{ii} / \rightarrow / \mathrm{i}: /)$ and glide deletion (e.g. $/ \mathrm{uwu} / \rightarrow / \mathrm{uu} / \rightarrow$ /u:/). In order to support this argument, many synchronic and diachronic pieces of evidence which suggest that this analysis of long vowels is capable of capturing significant generalizations about the shape of the basic stems in Arabic and the rules utilized for deriving the modified forms of these stems are presented (cf. Brame, 1970; Levy, 1971). In addition to the short and long monophthongs, MSA has two diphthongs, namely /aw/ and /aj/ (e.g. nawm 'sleeping', bayt 'house'). As for the permissible syllables in MSA, there are only five types which are listed below with illustrative examples:

1. a. CV (open, light): da-ra-sa 'he studied'

b. CVC (closed, heavy): $\min$ 'from'

c. CVV (open, heavy): qa:-ma: 'they (dual, masculine) stood up'

d. CVVC (closed, super-heavy): na:m 'he slept'

e. CVCC (closed, super-heavy): bint 'a girl'

\subsection{Aims of the Study}

This study attempts to explore the phonological processes that APs undergo during their derivation from triconsonantal verbs in MSA within the framework of autosegmental phonology. The AP, also known as the noun of agent and the noun of subject, is a nominal derivative of verbs which describes the entity that performs the action denoted by the verb from which it is derived (Al-Faxiri, 1996; Abd Al-Ghani, 2010; Al-Samurrai, 2013; among others). This nominal derivative belongs to the word class of substantives which consists of nouns and adjectives because it takes the same inflectional forms of this class, i.e., it is declined for definiteness (?alka:tib 'the writer', ka:tibun 'a writer') gender (e.g. za:Pirun 'a male visitor', za:Piratun 'a female visitor'), number (e.g. ba: $\underline{h i \theta}$ 'a researcher', ba: $\underline{\text { hiea:n}}$ 'two researchers', and ba:hiou:n 'researchers') and case (e.g. the active participle form mu'allim 'a teacher' is declined for the nominative, accusative and genitive cases in $m u^{c}$ allimun, $m u^{c}$ alliman and $m u^{c}$ allimin, respectively) (Ryding 2005, 102). In terms of syntax, the AP may function as a noun (e.g. the AP ta:libun 'a student' in the phrase ?ata: ta:libun 'a student came'), an adjective (e.g. the AP ba:ridun 'cold' in the phrase hawa:?un ba:ridun 'cold air'), an adverb (e.g. the AP muta?xxiratan in the phrase bada?at muta?xxiratan 'she started late') or a verb substitute (e.g. the AP na:Pimun in the phrase huwa na:Pimun 'he is sleeping') (Holes, 1995).

To make the examination feasible, one type of APs is chosen, namely the weak APs. Weak APs are chosen because they have a glide as one of their radicals. The APs which have glides are "more subject to various phonological rules than others, due to the instability of the glides in predictable phonological environment" (Mahadin, 1982, p. 211). The analysis of a category of APs that has glides can, thus, provide a more in-depth view of the phonological processes that are involved in their formation. Based on the position that the glide occupies, weak APs are classified into initially, medially, finally and doubly 
weak (Wright, 1896). One of the major proposals concerning these weak stems is that, despite having irregular surface representations, their underlying representations are parallel to those of their strong counterparts. The apparent irregularity of weak stems is ascribed to their susceptibility to various phonological rules due to the inherent instability of the glides that constitute at least one of the radicals (cf. Brame, 1970 and Mahadin, 1982).

The APs can be derived from the ten forms of Arabic verbal stems whether the stems are triconsonantal or quadriconsonantal, transitive or intransitive, strong or weak (Ryding, 2005; Abd AlGhani, 2010; Alshdaifat, 2014). This study is restricted to examining the derivation of APs from form I of the imperfective verb. This form is generally identified as the basic, or non-derived, form of verbs which serves as the base of derivation for the other nine forms of verbs. Form I of the imperfective verb has the pattern $\left|j a+C_{1} C_{2}\left\{\begin{array}{l}a \\ u \\ i\end{array}\right\} C_{3}\right|$ (e.g. ja-ktub 'he writes') which consists of the third person masculine prefix $|j a|$ and a triconsonantal stem that has one stem vowel. In addition to the $|j a|$, the unmarked prefix of the imperfective stem, a number of personal prefixes can attach to the imperfective stem such as $|\mathrm{Pa}|$, the first person singular prefix and |na|, the first person plural prefix. The $|j a|$ prefix and other prefixes and suffixes are not part of the base for deriving forms from the verb, rather only the stem of the verb is used as the base of derivation.

It should be indicated that most of the analyses of the AP derivation considered the stem of the perfective verb, rather than that of the imperfective, as the base from which triconsonantal APs are derived (e.g. Shahin, 1980; Al-Raagihi, 1984). In contrast to the usual practice among researchers, Mahadin (1982), Benmamoun (1999) and Abdo (2008), among others, presented valid arguments for employing the imperfective stem as the base of derivation of the AP and the other derived forms in Arabic. For instance, Mahadin (1982) argued that the vowel of the perfective stem can be predicated form the vowel of imperfective stem, but not vice versa. That is, the stem vowel of the imperfective is lexically determined in the sense that it cannot be predicated accurately by general rules and thus native speakers are assumed to store the imperfective stems in their mental lexicons along with the rules that derive their perfective counterparts. Following these researchers, the use of the imperfective stem, instead of its perfective counterpart, as the base from which the APs are derived is tested in the present study.

\subsection{Significance of the Study}

The significance of the present piece of research derives from the fact that it employs a relatively recent innovation in generative phonological analysis, viz. the autosegmental approach, that no other studies have applied to the examination of the phonological processes that APs undergo throughout their derivation. That is, despite the fact that many studies analyzed the derivation of APs, none of these studies conducted their analyses within an autosegmental framework. The autosegmental approach is considered an important approach to phonology because it overcomes various theoretical and empirical inadequacies of a dominant theory, viz. generative phonology, in the field of linguistics. It is significant to assess the adequacy of this approach in accounting for various phonological processes that take place in MSA; especially that some of its aspects are proposed specifically for the analysis of the unique characteristics of the Semitic family but are not exhaustively examined on a corpus of one of its main members. Premising the analysis on the modifications introduced to the classical analysis of Arabic phonology adds further importance to the study (cf. Aniis, 1975; Shahiin, 1980; Abdo, 2010). Furthermore, the studies that explore the phonology of Arabic do not generally rely on corpora for their analyses, rather these studies provide examples in support of their arguments which might affect the comprehensiveness and thoroughness of the analyses. Accordingly, present study aims at bridging a gap 
in the literature by employing the autosegmental approach of phonology for the analysis of an AP corpus which is built from a modern corpus-based dictionary.

\section{Method}

\subsection{Data Collection}

The first stage of the research involves building a corpus of APs from a well-established Arabic dictionary, namely $m u^{c} d z a m$ ?alluyah Pal'arabijjah Palmu'a:sirah 'Dictionary of Modern Arabic Language'. This dictionary (a four-volume work) is compiled by a large group of trained researchers lead by Omar in 2008 to cover the majority of words used in modern-day Arabic. One of the main goals of the dictionary compilers is avoiding the shortcomings of the pre-existing dictionaries. These shortcomings include mixing obsolete and common words in addition to excluding the new ones; building on earlier lexicographic work without conducting thorough examinations and failing to provide relevant morphological and semantic information (Omar, 2008). The dictionary is compiled from various written and auditory sources of MSA such as contemporary newspapers, news and news commentary programs, grammar books and dictionaries, children's stories and prominent publications on literature, psychology, law, economy, philosophy, history, arts, environment, technology, education, sports, science, etc.

The data from these sources are assembled in a corpus that contains more than one hundred million words. The large corpus is processed and analyzed statistically to include the common words in the dictionary and exclude the uncommon ones. The corpus-based monolingual dictionary, viz. $m u^{c} d z a m$ Palluyah Pal arabijjah ?almu ${ }^{c} a$ :sirah, is meant for the general user of the language and thus it contains words of general use that represent various spheres of life. This dictionary provides morphological and semantic information on the words it defines as well as plenty of illustrative examples of the contexts in which the different senses of these words are used.

The 32.300 alphabetized dictionary entries are grouped under 5.778 consonantal roots and are dedicated for verbs (10.475), nouns (21.457) and function words (368). Since the APs are derived from verbs, they are listed under verbal entries. The APs that are derived from triconsonantal weak verbs (form I) are listed in a corpus. The corpus contains 620 APs which are categorized, in accordance with the position of the glide in their stems, into initially, medially, finally and doubly weak APs. These are presented in Appendix (A), Appendix (B), Appendix (C), Appendix (D), respectively. It should be noted that the APs that have the same form are listed under separate entries in the corpus if they have different meanings (e.g. ja:min 'blessed' and ja:min 'turning right') or if they are derived from different imperfective verbs (e.g. the AP wa:biq 'perished' can be derived from the stems of the imperfective verbs $j a-b i q$ or $j a-w b a q)$.

\subsection{The Approach}

Autosegmental phonology is a non-linear approach to generative phonology proposed for overcoming the inadequacies of its linear counterpart. One of the main proposals of this approach is splitting the linear phonological representation into several tiers. These tiers consist of groups of autosegments and they are ordered independently of each other but are interconnected by means of association lines (McCarthy, 1982). The autosegmental structure of representation is originally proposed to handle suprasegmental features and thereafter its empirical domain is extended to various phonological areas. 
CV phonology is an autosegmental model designed by Clements and Keyser (1983) to represent the internal structure of syllable. This representation is composed of three tiers, i.e. the syllable node, CV and segmental tiers. The three-tier hierarchical structure of the syllable $/ \mathrm{men} / \mathrm{is}$ employed as an illustrative example below:

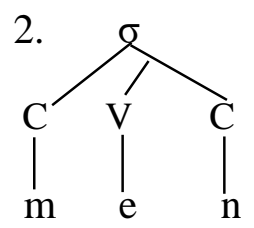

An advantage to utilizing distinct tiers for the characterization of the syllable structure is that the quantity of a segment can be referred to independently of its quality. In this regard, Spencer (1996) maintains that the CV tier is the level at which the quantity of a segment is represented, whereas its quality is described at the segmental tier. He refers to these tiers as the timing tier and melody tier, respectively. Employing these independent tiers facilitates accounting efficiently for the discrepancies between the quantity and quality of segments. To make this possible, a set of association conventions are used for connecting elements on these tiers.

Two of the major association conventions are the no-crossing constraint and the obligatory contour principle (OCP). The former prohibits the crossing of association lines and the latter prohibits identical adjacent segments at the segmental tier (Goldsmith, 1976). Adhering to these conventions allow accounting for cases in which the association between tiers is not formed in a one-to-one fashion. An example of a one-to-many association pattern is exemplified by complex segments, while a many-toone association between the CV tier and the segmental tier is found in the representation of long segments. Instances of the two types of association are presented, respectively in 3:

3. a.

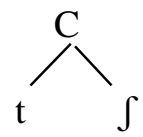

b.

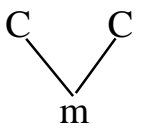

Providing an accurate account of the internal structure of segments is not the only advantage of CV phonology. Another key advantage of this model is that it utilizes a purely phonological unit, viz. the syllable, for the statement of phonological rules and phonotactic constrains. Accordingly, various phonological rules, such as consonantal deletion and vocalic epenthesis, are found to receive natural and simple notations because they are formulated in terms of the syllable notion (cf. Kenstowicz, 1994; Spencer, 1996).

The development of CV phonology involves introducing some modifications to this model. One of these modifications is based on considering the distinction between the $\mathrm{C}$ and $\mathrm{V}$ elements on the $\mathrm{CV}$ tier redundant and arguing that these elements are to be replaced with empty uniform positions labelled as $\mathrm{X}$ slots (Levin, 1985). A major impetus for the development of the X-slot model is ascribed to observing that $\mathrm{C}$ elements can be associated with vowels and $\mathrm{V}$ elements can be mapped to consonants. An example of this observation is found in the analysis of the frequent phonological process of compensatory lengthening. This process involves the lengthening of a segment triggered by the deletion an adjacent segment (Clements \& Keyser, 1983).

Hayes (1989, pp. 260-261) cites an example from Latin where "the segment /s/ was deleted before anterior sonorants." When the deleted /s/ followed a vowel, the vowel was lengthened in compensation. For instance, the deletion of the /s/ in the Latin word kasnus 'grey' causes the lengthening of its preceding vowel ka:nus. Within autosegmental phonology, the autonomy given for elements that occupy different tiers enables providing a straightforward account of the compensatory lengthening process. 
That is, the deletion of the /s/ takes place only on the segmental tier which leaves its C element, or timing slot, empty (ibid, p. 261). The empty timing slot spreads to the vowel that precedes the deleted /s/ forming the long vowel /a:/.

Despite that fact that compensatory lengthening lends itself to being analyzed within the autosegmental approach, the CV model of this approach faces a challenge in the analysis of this process. The challenge is that the empty timing slot was attached to the consonant /s/ and thus it is assumed to be specified as [+consonantal]. Spreading an empty $\mathrm{C}$ slot to a vowel melody is problematic. To resolve this problematic issue, the $\mathrm{C}$ and $\mathrm{V}$ slots are replaced with $\mathrm{X}$ slots unspecified for the feature [ \pm consonantal]. An X-slot analysis of the compensatory lengthening of the /a/ sound in the Latin word ka:nus is adopted from Hayes (1989, p. 261) and used as an illustrative example below:

4.

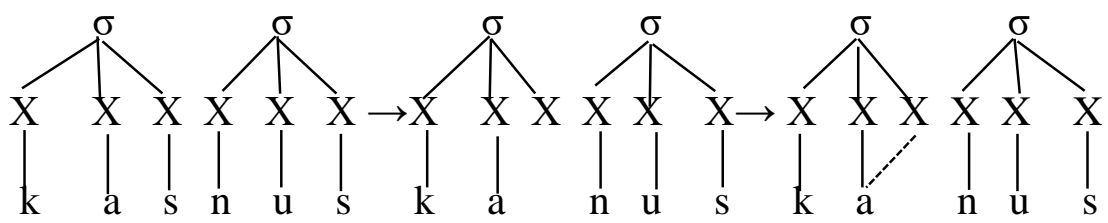

\section{Results and Discussion}

In line with Al-Faxiri (1996), Abd Al-Ghani (2010), Al-Samurrai (2013), among others, the analysis of the current AP corpus reveals that all the 620 instances of the APs which are derived from weak imperfective verbs (form I) are on the pattern $\left|\mathrm{C}_{1} \mathrm{a}: \mathrm{C}_{2} \mathrm{iC}_{3}\right|$. Accordingly, the present analysis of the derivation of the APs is restricted to the pattern $\left|\mathrm{C}_{1} \mathrm{a}: \mathrm{C}_{2} \mathrm{iC}_{3}\right|$. Table 3 below presents the frequencies of the initially, medially, finally and doubly weak APs that are analyzed in this study.

Table 3. The Frequencies of the Four Types of APs

\begin{tabular}{llllll}
\hline APs of the pattern & Initially- & Medially-weak & Finally-weak & Doubly-weak & Total \\
$\left|\mathrm{C}_{1} \mathrm{a}: \mathrm{C}_{2} \mathrm{iC}_{3}\right|$ & weak APs & APs & APs & APs & \\
Frequencies & 99 & 264 & 230 & 27 & 620 \\
Percentages & $16 \%$ & $42.6 \%$ & $37 \%$ & $4.4 \%$ & $100 \%$ \\
\hline
\end{tabular}

As can be shown in Table 3, the most frequent AP type is the medially-weak which constitutes $42.6 \%$ of the AP corpus. It is followed by the finally-weak type which accounts for $37 \%$ then the initially-weak type which accounts for $16 \%$ and finally the doubly-weak type which accounts for $4.4 \%$. The following sections attempt to analyze these four types of APs starting with the imperfective stems from which they are derived.

\subsection{Initially-Weak Aps}

\subsubsection{The Imperfective Stems of Initially-Weak APs}

Form I of initially-weak imperfective stems from which APs on the pattern $\left|\mathrm{C}_{1} \mathrm{a}: \mathrm{C}_{2} \mathrm{iC}_{3}\right|$ are derived have the underlying representation $\left|\mathrm{GC}_{2} \mathrm{VC}_{3}\right|$. The first radical in these stems, i.e. the glide, can be a /w/ or a /j/. Mahadin (1982) argued that the majority of initially-weak imperfective stems begin with a /w/ and a very few of them begin with a $/ \mathrm{j} /$. According to him, the initially-weak imperfective stems that begin with the $/ \mathrm{w} /$ have the following surface representations: 
5. a. $\left|\mathrm{C}_{2} \mathrm{i}_{3}\right|$ (e.g. ja-sil 'he arrives')

b. $\left|\mathrm{wC}_{2} \mathrm{uC}_{3}\right|$ ('e.g. ja-wfur 'it is abundant')

c. $\left|\mathrm{wC}_{2} \mathrm{aC}_{3}\right|$ (e.g. ja-wdzal 'he is scared')

d. $\left|\mathrm{C}_{2} \mathrm{aC}_{3}\right|$ (e.g. ja-d $\mathbf{a}^{\mathrm{c}}$ 'he puts')

As can be noted, the $/ \mathrm{w} /$ is deleted in the imperfective stems which are shown in (a) and (d). Mahadin (1982) and Brame (1970) argued that the glide / $\mathrm{w} /$ is deleted when the stem vowel is / $\mathrm{i} /$ and it remains when the stem vowels are $/ \mathrm{u} / \mathrm{or} / \mathrm{a} /$. The $\mathrm{w}$-deletion rule is stated as follows:

6.
[personal prefix]

The w-deletion rule stipulates that the $/ \mathrm{w} /$ is deleted when it is preceded by a personal prefix, in this case the third person masculine prefix ' $\mathrm{ja}$ ' and followed by a $\left|\mathrm{C}_{2} \mathrm{iC}_{3}\right|$ sequence. The rule only applies to basic, i.e. non-derived or form I, verbs when their stem vowel is /i/. Mahadin (1982) and Brame (1970) argued that the deletion of the glide / $\mathrm{w} /$ in some of the imperfective stems that have the stem vowel /a/ does not contradict the w-deletion rule. This is attributed to the assumption that the stem vowel of the imperfective forms that are exemplified in (d) is originally /i/ but it becomes /a/ through the application of the laryngeal-assimilation rule.

This rule requires changing the vowel $/ \mathrm{i} /$ into $/ \mathrm{a} /$ in non-derived imperfective stems when it is adjacent to a laryngeal, where laryngeal includes "those sounds produced in the area extending from the larynx to the upper regions of the pharynx" (Brame, 1970, p. 159). As can be noted from the definition, the term laryngeal encompasses not only the laryngeals but also the pharyngeal and uvular sounds. Accordingly, the laryngeal assimilation rule, as stated in 7 below, is assumed to apply to these three categories of sounds which are subsumed under the guttural category in the present analysis and it is consistent with the lowering effect this category of sounds has on adjacent vowels (cf. McCarthy, 1994).

$$
\text { 7. } \mathrm{i} \rightarrow \mathrm{a} / \mathrm{L}_{\mathrm{L}-\mathrm{L}}^{\mathrm{L}} /\left(\begin{array}{c}
+ \text { imperfect } \\
- \text { derived }
\end{array}\right)
$$

The w-deletion and the laryngeal assimilation rules apply in an ordered sequence to the imperfective stems that are exemplified in (d). The former rule deletes the $/ \mathrm{w} /$ from imperfective verbs of the pattern |ja-wCiL $\mid$ or $|j a-w L i C|\left(e . g . j a-w \underline{d} i^{c} \rightarrow j a-\underline{d} i^{c}\right.$ 'he puts') because they meet the deletion conditions. After the deletion of the /w/, the latter rule applies to $|\mathrm{ja}-\mathrm{CiL}|$ or $\mathrm{ja}-\mathrm{LiC} \mid$ and changes the stem vowel /i/ to /a/ because it is adjacent to a laryngeal (e.g. $j a-\underline{d} i^{c} \rightarrow j a-\underline{d} a^{c}$ ). As for the non-derived imperfective stems which begin with the glide /j/, they are always on the pattern $|j a-j C V C|$ which indicates that the glide /j/ is not subjected to the deletion rule which affects its counterpart, i.e. the /w/ (e.g. ja-jias 'he loses hope') (Mahadin, 1982).

One can conclude from the analysis of form I of the imperfective stems from which initially-weak APs are derived that all of them share the underlying pattern $\left|\mathrm{GC}_{2} \mathrm{VC}_{3}\right|$ and that the deletion of the glide in some of their surface representations is ascribed to the application of certain phonological processes. Accordingly, all of the initially-weak APs in the present analysis are assumed to be derived from bases on the pattern $\left|\mathrm{GC}_{2} \mathrm{VC}_{3}\right|$.

\subsubsection{The Derivation of Initially-Weak APs from their Imperfective Stems}

In the analyses of the derivation of APs from initially-weak verbs, there is a general agreement that they are derived in much the same way as those of strong verbs (Al-Raagihi, 1984; Ryding, 2005; Abd 
Al-Ghani, 2010; Al-Samurrai, 2013). The regularity of the derivation of form I APs from initially-weak verbs implies that all the radicals in the underlying representation of the verbal stem, i.e. the source of derivation, are retained in the AP form, i.e. the target of derivation.

Within the analyses that adopted the insights of classical Arabic grammarians, the derivation of the AP (form I) from initially-weak verbs, akin to its derivation from strong verbs, merely involves placing the perfective verb (form I) on the pattern $\left|\mathrm{C}_{1} \mathrm{a}: \mathrm{C}_{2} \mathrm{i} \mathrm{C}_{3}\right|$ (e.g. the perfective verb wadzad 'he found' is placed on this pattern to derive its AP form wa:dzid 'a finder'). A more intricate analysis of this derivation process is carried out by Brame (1970) who argued, on the basis of the hypothesis that there are no long vowels in the underlying level of representation in Arabic, that the long vowel /a:/ does not exist in the underlying representation of the pattern $\left|\mathrm{C}_{1} \mathrm{a}: \mathrm{C}_{2} \mathrm{iC}_{3}\right|$, rather it only appears in its surface representation. He maintained that the derivation of APs on the pattern $\left|\mathrm{C}_{1} \mathrm{a}: \mathrm{C}_{2} \mathrm{iC}_{3}\right|$ entails the infixation of /wa/ into the perfective stem.

The infixation of /wa/ to the perfective stem produces the form $\left|\mathrm{CawaC}_{2} \mathrm{iC}_{3}\right|$ (e.g. wadzad 'he found' wawadzid). The $/ \mathrm{w} /$ in the form $\left|\mathrm{CawaC}_{2} \mathrm{iC}_{3}\right|$ occurs in intervocalic position which triggers its deletion by the application of the glide elision rule (wawadzid $\rightarrow$ waadzid). Afterwards, the two adjacent /a/ vowels in $\left|\mathrm{CaaC}_{2} \mathrm{iC}_{3}\right|$ are combined into a single long vowel through the application of a lengthening rule (waadzid $\rightarrow$ wa:dzid). The /wa/-infixation, the glide elision and the lengthening rules are, respectively, stated in 8 below:

$$
\begin{aligned}
& \text { 8. a- wa }[\mathrm{CVX} \rightarrow[\mathrm{CVwaX} \\
& \text { b- } \mathrm{G} \rightarrow \emptyset / \mathrm{V}_{\mathrm{i}} \_\mathrm{V}_{j}, \text { if } \mathrm{j}=[+ \text { low }], \mathrm{i}=[+ \text { low }] \\
& \text { c- } \mathrm{V}_{\mathrm{i}} \mathrm{V}_{\mathrm{i}} \rightarrow \mathrm{V}_{\mathrm{i}}:
\end{aligned}
$$

Brame (1970) asserted that the infixation of /wa/ in the course of the derivation of APs (form I) is plausible because the derivation of all the forms of the participles, whether they are active or passive, requires attaching a prefix to the verbal stem. The underlying representation of the participle prefix is $/ \mathrm{ma} / \mathrm{which}$ is turned into $/ \mathrm{mu} /$ in the derived forms, i.e. forms other than form I, of the participles and turned into /wa/ when used as an infix. The rules that stipulate alternating $/ \mathrm{ma} / \mathrm{into} / \mathrm{mu} / \mathrm{or} / \mathrm{wa} / \mathrm{are}$ given below:

9. $\mathrm{a}-\mathrm{ma} \rightarrow \mathrm{mu} /[+$ derived $]$

$$
\text { b- } \operatorname{ma}[\mathrm{CVX} \rightarrow \mathrm{CVmaX} \rightarrow \mathrm{CVwaX}
$$

Brame (1970) proposed that the glide /w/ is part of APs (form I) affix because it surfaces in some of the forms to which the affix is added. This proposal is considered plausible by Mahadin (1982) who established that the affixes which are added to modify the meaning of the basic stem should have the shape of the syllable, i.e. $|\mathrm{CV}|$, and not of a single segment.

Changing the affix /wa/ to the long vowel /a:/ can be accounted for straightforwardly if the imperfective stem is employed as the base of derivation. That is, the imperfective stems have underlying representations of the shape $\left|\mathrm{C}_{1} \mathrm{C}_{2} \mathrm{VC}_{3}\right|$ in which there is no vowel between their first and second consonants. As mentioned in Section 1, the syllables that begin with a cluster of two consonants are not permissible in MSA. For this reason, the imperfective stem can never surface without a personal prefix of the shape $|\mathrm{CV}|$. The addition of a $|\mathrm{CV}|$ prefix to the imperfective stem results in the re-syllabification of the stem by placing its first consonant in the coda position of the first syllable and its second consonant in the onset position of the second syllable. The resultant sequence, i.e. $\left|\mathrm{CVC}_{1}-\mathrm{C}_{2} \mathrm{VC}_{3}\right|$, is composed of two permissible syllables and thus it can appear as a surface representation (e.g. jak-tub 'he writes').

Infixing the /wa/, or any affix with a $|\mathrm{CV}|$ shape, to an imperfective stem to derive to its AP form causes the creation of a cluster of two consonants in the onset position of the syllable $\left|\mathbf{C}_{1} \mathbf{w a C}_{2} \mathrm{VC}_{3}\right|$. This triggers the application of a deletion rule which deletes the $/ \mathrm{w} /$ and the lengthens its adjacent vowel in 
compensation (cf. Section 2.2). In the adopted model of autosegmental phonology, the representation of the deletion and the compensatory lengthening, as depicted in 10, involves deleting the / $/ \mathrm{w} /$ melody from the segmental tier and spreading its empty $\mathrm{X}$-slot to its following vowel.

10.

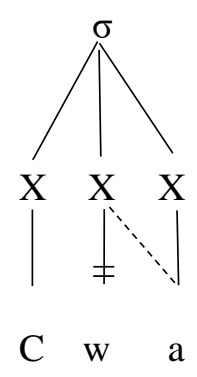

In addition to the insertion of the /wa/ infix between the first and second consonant, another modification to the imperfective stem to derive its AP form is changing the stem vowel, which might be an /a/, /u/ or /i/, to /i/ $\left(\mathrm{C}_{1} \mathrm{C}_{2}\left\{\begin{array}{c}\mathbf{a} \\ \mathbf{u}\end{array}\right\} \mathrm{C}_{3} \rightarrow \mathrm{C}_{1} \mathrm{C}_{2} \mathbf{i} \mathrm{C}_{3}\right)$. This requires the application of an ablaut rule, i.e. a rule that involves systematic alterations in the stem vowel to indicate modifications of meaning or inflectional information, which changes the features of the stem vowel to [+high] and [-rounded]. As can be noted, the application of the compensatory lengthening and the ablaut rules need not to be ordered because neither of these rules affects the other.

The derivation of the 99 initially-weak APs in the analyzed corpus, as shown in Appendix (A), from their imperfective stems show no deviation from the general pattern. For instance, the derivation the AP form $w a:^{c} i \underline{\partial}$ 'a preacher' from $w^{c} i \underline{\partial}$, i.e. the underlying representation of the stem of the imperfective verb $j a{ }^{c} i \underline{\partial}$ 'he preaches', involves infixing the /wa/ between the $/ \mathrm{w} /$ and $/ \%$, i.e. its first and second consonants, respectively. Afterwards, the /wa/ is changed to /a:/ through the application of the compensatory lengthening process. As for the ablaut rule that changes the stem vowel to $/ \mathrm{i} /$, there is no need for its application because the stem vowel of the verb $j a-{ }^{c} i \underline{d}$ is already /i/. The derivation of wa: ${ }^{c} i \underline{\partial}$ from its imperfective stem is shown in 11 below:

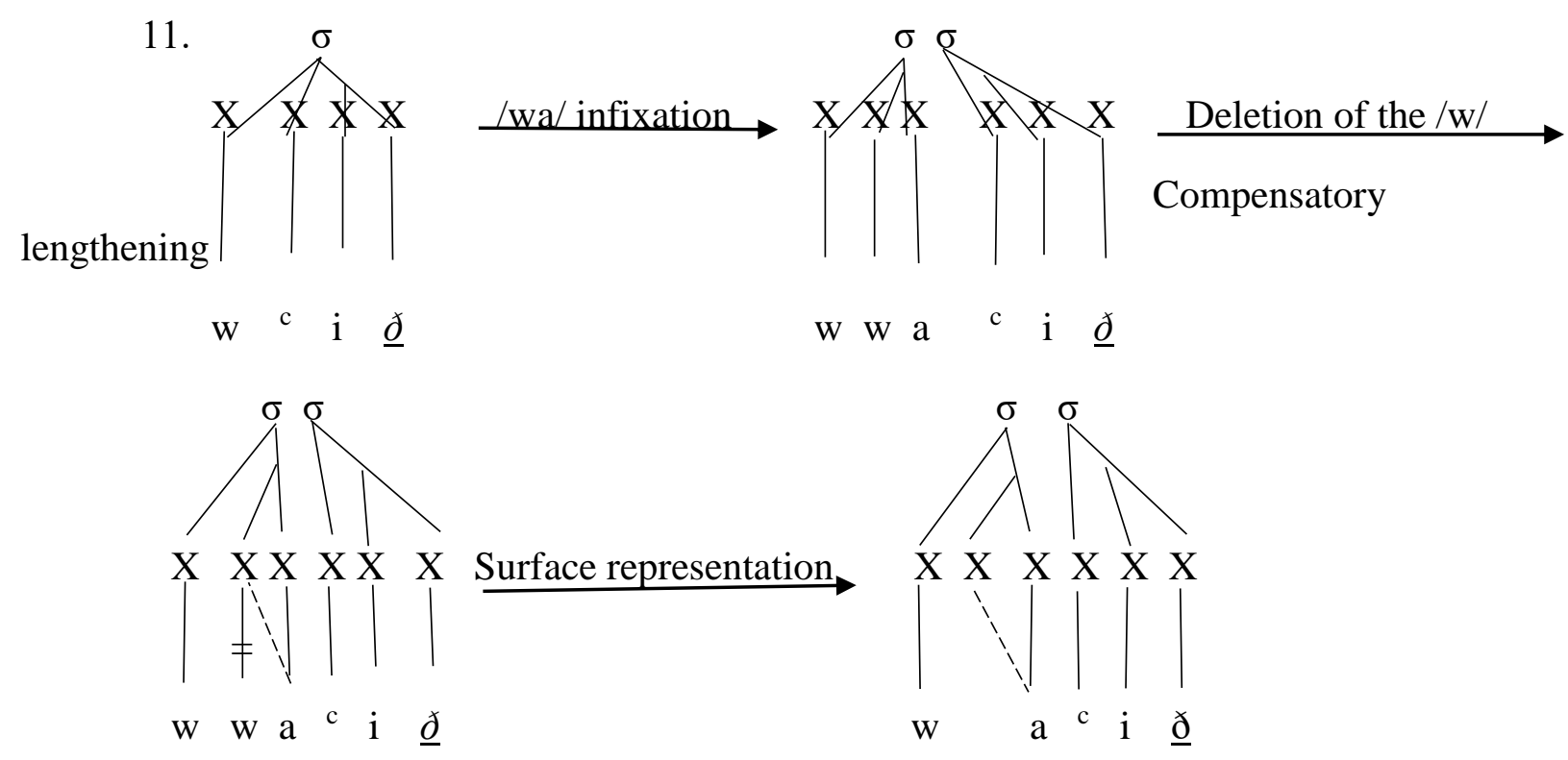




\subsection{Medially-Weak APs}

\subsubsection{The Imperfective Stems of Initially-Weak APs}

The surface representations of medially-weak imperfective stems are on the pattern $\left|C_{1} V: C_{3}\right|$. This pattern is composed of two consonants and a long vowel and hence these stems are apparently biconsonantal. Based on the hypotheses that there are no long vowels in MSA underlying representations and that weak stems have the same structures as those of the strong stems, the medially-weak imperfective stems have underlyingly a pattern that resembles their strong counterparts, i.e. $\left|\mathrm{C}_{1} \mathrm{C}_{2} \mathrm{VC}_{3}\right|$. The second consonant of these stems is generally assumed to be a glide that surfaces as a vowel due to its susceptibility to various phonological process (cf. Brame, 1970; Levy, 1971). Even though the glide does not exist in form I of the imperfective verb, it exists in the derived forms of the verb (e.g. ja-xa:f 'he fears' (form I) and ju-xawwif 'he causes someone to fear' (form II)). Accordingly, all the mediallyweak imperfective stems have the underlying shape $\left|\mathrm{C}_{1} \mathrm{GVC}_{3}\right|$ which surfaces as $\left|\mathrm{C}_{1} \mathrm{~V}: \mathrm{C}_{3}\right|$ through the application of certain phonological processes.

Brame (1970) accounted for the surface representation of medially-weak imperfective stems by proposing a glide metathesis rule which applies to the sequence CGVC and metathesizes the glide and the stem vowel (e.g. $j a^{-}{ }^{c} \boldsymbol{w} \boldsymbol{u d} \rightarrow j a^{-}{ }^{\boldsymbol{c}} \boldsymbol{u} \boldsymbol{w d}$ ). After the application of this rule, an assimilation rule applies to the sequence CVGC and assimilates the glide to its following vowel (e.g. ja- ${ }^{c} \boldsymbol{u w d} \rightarrow j a-{ }^{c} \boldsymbol{u} \boldsymbol{u d}$ ). Finally, the two short identical vowels in the resultant sequence $\mathrm{CV}_{\mathrm{i}} \mathrm{V}_{\mathrm{i}} \mathrm{C}$ are combined into a single long

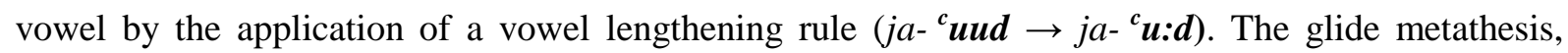
assimilation and lengthening rules are, respectively, stated in 12 .

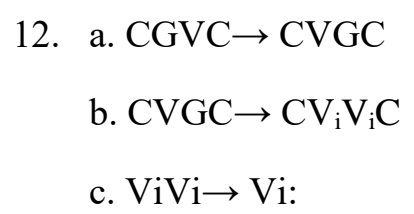

Mahadin (1982) regarded Brame's (1970) analysis as being partially incorrect because of its inability to account for the $|\mathrm{aG}|$ sequence. This is ascribed to the permissibility and as such the general stability of the $|\mathrm{aG}|$ sequence, as opposed to the $|\mathrm{uG}|$ and $|\mathrm{iG}|$ sequences, in Arabic. This can be manifested in the facts that the only two diphthongs in Arabic have the $|\mathrm{aG}|$ shape, i.e. /aj/ and /aw/, and that the $|\mathrm{aG}|$ sequence does not undergo Brame's (1970) assimilation rule in finally-weak verbs (e.g. ramayna 'we threw') and in the verbal nouns with the shape $|C V G C|$ (e.g. the /aj/ and /aw/ sequences are stable in the verbal nouns xawf 'fear' and $b a j$ c 'selling').

Mahadin (1982) proposed another rule to account for the surface representation of medially-weak verbs in Arabic. This rule, as shown in 13, applies to the sequence $|C G V|$ when it is preceded by a morpheme boundary (\#), such as the morpheme boundary of the personal prefix /ja/ in ja\#t wud 'he comes back', and causes the assimilation of the glide to its following vowel which results in the sequence $\left|C V_{i} V_{i}\right|$. The assimilation rule is followed by the vowel lengthening rule which is stated in 12 (c).

\section{3. $\# \mathrm{CGV}_{\mathrm{i}} \rightarrow \mathrm{CV}_{\mathrm{i}} \mathrm{V}_{\mathrm{i}}$ (\# designates morpheme boundary)}

As can be noticed, this assimilation rule only applies to the $|\mathrm{CGV}|$ and not to metathesized $|\mathrm{CVG}|$ and this prevents its application to the stable $|\mathrm{aG}|$ sequence. Moreover, Mahadin $(1982,255)$ maintained that specifying the conditioning environment of the rule prevents it from applying to the finally-weak verbs and verbal nouns in that the two of them are not preceded by morpheme boundary. He further asserted that this assimilation rule also applies to various forms of nouns such as the nouns of place ma\#tyar and ma\#qwam which surface as ma\#ta:r 'airport' and ma\#qa:m 'site', respectively (ibid, 256). 
The rule that is proposed by Mahadin (1982) accounts for cases where the glide assimilates to its cognate vowels, i.e. the assimilation of the $/ \mathrm{w} /$ and $/ \mathrm{j} /$ to the $/ \mathrm{u} /$ and $/ \mathrm{i} /$, respectively, but it faces problems in accounting for the assimilation of the glide to its non-cognate vowel, e.g. the assimilation of the /w/ to the /a/. This is ascribed the general assumption that the source and the target of assimilation processes should be phonetically similar (cf. Kenstowicz, 1994; Spencer, 1996). A straightforward analysis of the surface forms of medially-weak stems can be provided if the X-slot model of autosegmental phonology is adopted. That is, the glide in the sequence $\left|\# C G V_{i}\right|$ undergoes a glide elision process, instead of the glide assimilation process, and its adjacent vowel is lengthened in compensation. The statement of this process in the $\mathrm{X}$-slot model of phonology is depicted in 14 .

14.

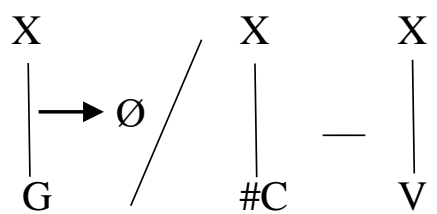

\subsubsection{The Derivation of Medially-Weak APs from their Imperfective Stems}

In contrast to the derivation of the $\left|\mathrm{C}_{1} \mathrm{a}: \mathrm{C}_{2} \mathrm{i}_{3}\right|$ pattern from initially-weak verbs which resembles its derivation from strong verbs, this pattern shows some modifications when it is derived from mediallyweak verbs. Traditional Arab linguists, such as Ibin Jinni, 1954; Sibawayh, 1982 and Ibin Asfor, 1987, and the researchers who followed their leads, such as Al-Raagihi, 1984; Al-Faxiri, 1996; Abd Al-Ghani, 2010 and Al-Samurrai, 2013, argued that the medially-weak perfective verbs from which the APs are assumed to be derived generally have the letter Palif, which corresponds to the long vowel /a:/, as their second radical (e.g. $b a:^{c}$ 'he sold'). The Palif is substituted with the glottal stop/?/ when these verbs are placed on the pattern $\left|\mathrm{C}_{1} \mathrm{a}: \mathrm{C}_{2} \mathrm{C}_{3}\right|$ to derive their AP forms (e.g. the Palif of the verb $b a:^{c}$ 'he sold' is realized as / $/$ / when it is placed on the pattern $\left|\mathrm{C}_{1} \mathrm{a}: \mathrm{C}_{2} \mathrm{C}_{3}\right|$ to derive the AP $b a: P i^{c}$ ' a seller').

Brame (1970) contended that the APs (form I) are expected to retain the three consonants, or radicals, of their medially-weak perfective bases. However, one of these radical, i.e. the second one which is originally a glide, is substituted with a glottal stop in the surface representation of these APs (e.g. the APs sa:wid and za:jid surface as sa:Pid 'prevailing' za:Pid 'increasing' by inserting a glottal stop in the place of their medial glides). To account for this alternation, he proposed a rule that changes a glide to a glottal stop when it is preceded by /a:/ and followed by a short vowel and called it the glottal formation rule. The glottal formation rule is also observed to apply to a broken plural form of nouns (e.g. the plural form of dari:batun 'a tax' surfaces as dara:Pibun 'taxes' instead of dara:jibun due to changing the /j/ which occurs between /a:/ and a short vowel into the /P/). This rule is given in 15 .

15. G $\rightarrow$ ? / a:_V

Abdo (2010) assumed that the glottal stop / $/$ / is infixed after the first stem vowel in these AP forms (e.g. qawil $\rightarrow$ qaPwil). Subsequently, a glide metathesis rule switches the position of the infixed / $/$ and its following glide (qa?wil $\rightarrow$ qaw?il). The glide metathesis is followed by an assimilation rule that assimilates the glide to its preceding vowel (qaw?il $\rightarrow$ qaa?il). Finally, a vowel lengthening rule combines the two identical adjacent vowels into a single long one (qaa?il $\rightarrow$ qa:?il 'a teller').

A problematic issue in these analyses is that the /a:Gi/ sequence in medially-weak APs surfaces in other nominal and verbal forms without undergoing any phonological processes. Examples of these forms are presented in 16.

16. a. ju-qa:wim 'he resists' (imperfective verb)

b. qa:jid 'trade' (imperative verb)

c. mu-qa:wil 'a contractor' (active participle) 
Even though the alternation between glides and the glottal stop is stated as a general rule, the examples of this alternation are only drawn from two forms (cf. Ibin Jinni, 1954; Brame, 1970; Sibawayh, 1982; Ibin Asfor, 1987; Al-Nuri, 2007). The first is the AP (form I) and second is the broken plural form on the pattern $\left|\mathrm{C}_{1} \mathrm{aC}_{2} \mathrm{a}: \mathrm{C}_{3} \mathrm{C}_{4}\right|$. One can argue, in line with Brame (1970), that the infixed /a:/ in these two forms is underlyingly /wa/. Based on this argument, the underlying pattern of the mediallyweak APs and the broken plural form are $|\mathrm{CwaGiC}|$ and $\left|\mathrm{C}_{1} \mathrm{aC}_{2} \mathrm{waGiC}_{4}\right|$, respectively.

In both of these patterns, the glide occurs between two short vowels and this triggers its deletion by the glide elision rule which is stated 8 (b). The deletion of the glide results in making its syllable onsetless. Because onsetless syllables are not allowed in MSA, a prosthetic glottal stop is inserted to function as the onset of the onsetless syllable (cf. Abu Salim, 1988; Żygis, 2010). The representation of the derivation of medially-weak APs from their imperfective stems in the X-slot model of autosegmental phonology is exemplified by the AP qa:?im 'standing' which is shown in 17.

17. a.

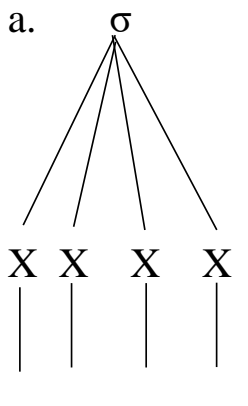

Infixing /wa/

q $\quad$ w $\quad$ u $\quad m$

Alternating the stem vowel into /i/
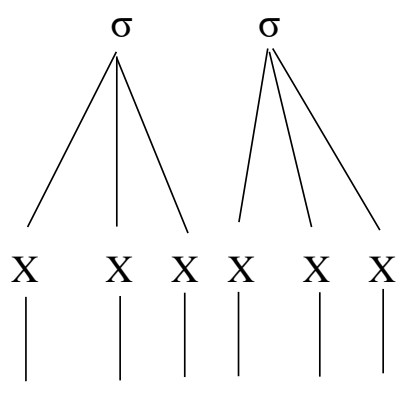

q $\quad$ w $\quad$ a $\quad$ w $\quad$ i $\quad m$
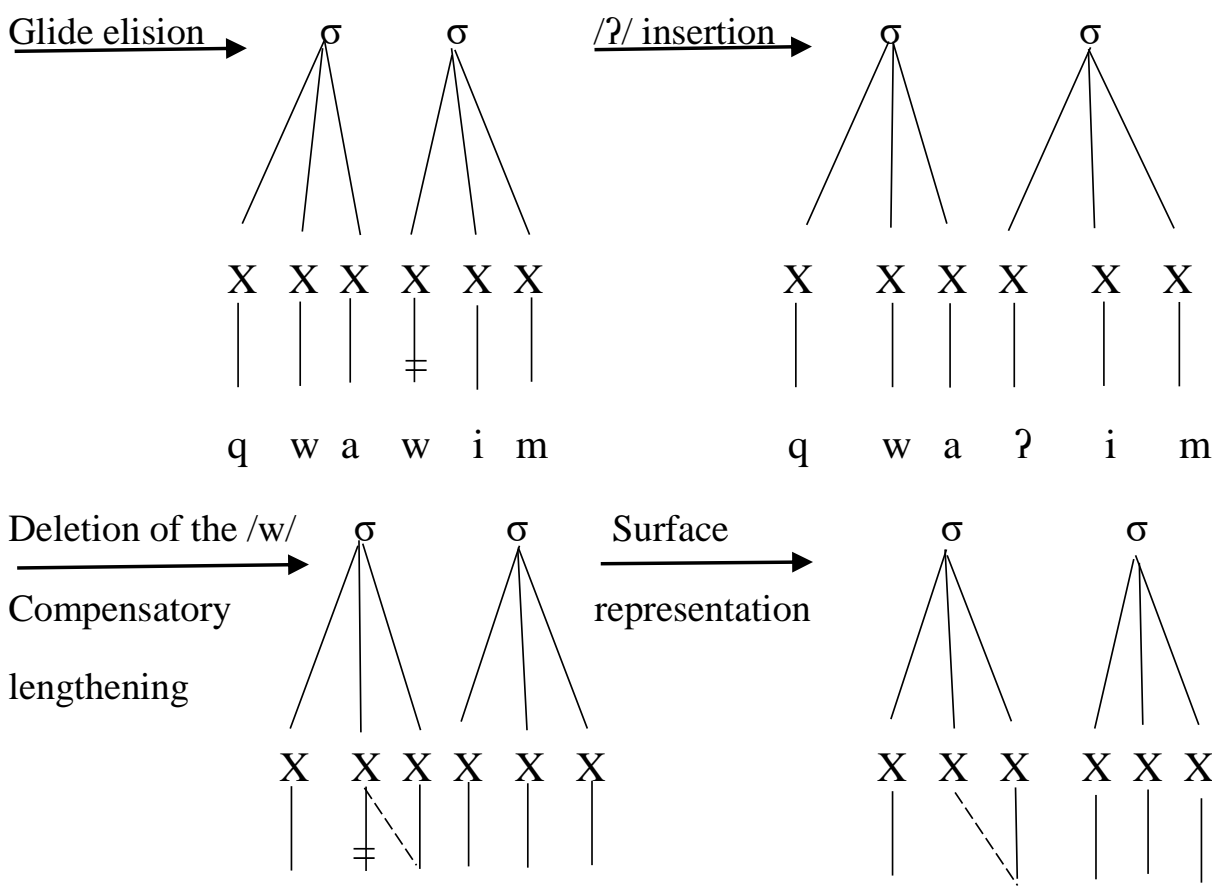

q $\quad$ w

q

a $\quad$ ? $\quad$ i $\mathrm{m}$

As can be shown in 17, the underling representation of the stem of the imperfective verb ja-qu:m 'he stands up' is qwum. The derivation of its AP form requires inserting the infix /wa/ between its first and second consonants and alternating its stem vowel into $/ \mathrm{i} /$. The second $/ \mathrm{w} /$ in the resultant sequence, i.e. qwawim, occurs between the two short vowels /a/ and /i/ and thus it is subjected to the glide elision rule. The deletion of $/ \mathrm{w} /$ causes the production of an onsetless syllable which triggers the application of a 
glottal epenthesis process. Finally, the /w/ in the sequence qwarim is deleted to avoid violating the constrain on complex onsets in MSA syllable structure and its empty X-slot spreads to its following vowel which yields the surface representation qa:?im 'standing'.

The 264 medially-weak APs, as presented in Appendix (B), that are analyzed in the current study are found to be regularly derived following this pattern except for six, which are shown in Table 4. It should be noted that these six AP forms are listed in the current corpus in the pattern |Ca:Pin| instead of |Ca:Pi:| because the nominative or genitive case markers and the indefinite suffix $/ \mathrm{n} /$ are attached to the forms that end with a long vowel in the dictionary from which the current corpus is built (see Section 3.3.2).

Table 4. Medially-Weak APs which Deviate from the Derivational Pattern

\begin{tabular}{|c|c|c|c|c|c|}
\hline $\begin{array}{l}\text { Dictionary } \\
\text { number }\end{array}$ & entry & Consonantal root & Imperfective verb & Gloss & Active participle \\
\hline 804 & & $\mathrm{~b} w ?$ & ja-bu:? & to deserve & ba:?in \\
\hline 3151 & & $\mathrm{~d} w$ ? & ja-du:? & to be lightened up & $\underline{\text { da:Pin }}$ \\
\hline 3902 & & $f j$ ? & ja-fi:? & to return & fa:Pin \\
\hline 4148 & & $\mathrm{qj}$ ? & ja-qi:? & to vomit & qa:?in \\
\hline 5265 & & $\mathrm{n} w$ ? & ja-nu:? & to burden & na:?in \\
\hline 5492 & & h j ? & ja-ha:? & to look good & ha:?in \\
\hline
\end{tabular}

As can be observed from Table 4, the imperfective verbs of these APs end with a glottal stop. The insertion of a glottal stop in the course of deriving their AP forms results in the sequence |Ca:?i?| which has a glottal stop as its second and third radicals. The sequence |Ca:?i?| surfaces as |Ca:?i:|. The surface representation of this sequence is consistent with Sibawayh (1982) who argued that adjacent glottal stops are not allowed in SA. In the current model of analysis, one can simply postulate that the second $/ \mathrm{R} /$ is deleted in accordance with the OCP and its preceding vowel is lengthened in compensation, as depicted in

18.

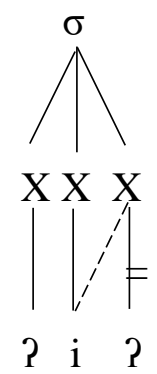

Accounting for the alternation of the / $\mathrm{Pi} /$ / sequence into / $\mathrm{i}$ :/ is only possible in the X-slot model of autosegmental phonology. This is ascribed to the observation that the $/ \mathrm{P} /$ is not phonetically similar to the /i/ and thus it cannot assimilate to it which leaves its deletion as the only option for avoiding the adjacency of glottal stops. The deletion of a segment in the standard approach of phonology entails eliminating both its quantity and quality. On the other hand, the deletion of a segment within autosegmental phonology only takes place on the segmental tier, which represents the quality of segments, which leaves its quantity, represented in the CV tier or X-tier, intact and capable of spreading to its adjacent segment.

Moreover, utilizing the X-slot model of autosegmental phonology instead of the CV model of this approach for the representation of this instance of compensatory lengthening is attributed to the fact that the quantity, or timing, slots in the former model are not specified for the feature [ \pm consonantal]. This enables accounting for the compensatory lengthening cases which are triggered by the deletion of a consonant and the lengthening of its adjacent vowel in compensation (see Section 2.2). 


\subsection{Finally-Weak Aps}

\subsubsection{The Imperfective Stems of Finally-Weak APs}

The surface representations of finally-weak verbs are on the pattern $\left|\mathrm{C}_{1} \mathrm{C}_{2} \mathrm{~V}:\right|$. The long vowel in the pattern $\mid \mathrm{C}_{1} \mathrm{C}_{2} \mathrm{~V}$ :| appears as /u:/ (e.g. ja-ndzu: 'he survives'), /i:/ (e.g. ja-bri: 'he sharpens'), /a:/ (e.g. jarqa: 'he advances'), or alternative /a:/ and /i:/ (ja- $\gamma \theta a$ : and $j a-\gamma \theta i$ : 'he talks a lot'). Proposing that the underling representation of finally-weak imperfective verbs, as well as the other weak imperfective verbs, is identical to those of their strong counterparts, requires identifying the phonological processes that change their underling representation, i.e. $\left|j a-C_{1} C_{2} V G\right|$, to their surface representation, i.e. ja$\mathrm{C}_{1} \mathrm{C}_{2} \mathrm{u}$ :|. In this regard, Mahadin (1982) observed that most of the changes to the underling representations of finally-weak verbs are triggered by the interaction between their stems and the suffixes that are attached to them. He maintained that the third radical of finally-weak verbs, i.e. the glide, is regularly deleted when these verbs inflect for their indicative case. The deletion is caused by the glide elision rule, as stated in 8 (b), which takes place when a glide occurs between two vowels $\mathrm{VGV}$, except for when the first vowel is high and the second is low, i.e. $\mathrm{uGa}$ and iGa.

For instance, the addition of the indicative case suffix /u/ to the imperfective verb ja-d $d^{c} u w$ 'he invites' causes the occurrence of the glide /w/ between two high vowels, i.e. $|\mathrm{uGu}|$, which triggers its deletion by the glide elision rule. Subsequently, the two identical short vowels become one long vowel by the application of the vowel lengthening rule which is stated in 12 (c). The application of these phonological processes changes the underlying representations of the imperfective verb $j a-d^{c} u w$ to its surface representation, i.e. $j a-d^{c} u$ : 'he invites, indicative case'.

On the other hand, the addition of the subjunctive case suffix /a/ to ja- $d^{c} u w$ places the glide /w/ between the high vowel $/ \mathrm{u} /$ and the low vowel /a/. The sequence $\mid \mathrm{uGa}$ | does not undergo the glide elision rule and thus this imperfective verb surfaces as $j a-d^{c} u w a$ 'he invites, subjunctive case'. The addition of the subjunctive case suffix does not always result in retaining the glide of finally-weak verbs. For example, inflecting the imperfective verb ja-lqaj 'he encounters' for the subjunctive case results in the sequence $j a-l q a j-a$. Because the glide / $\mathrm{j} /$ in this sequence occurs between two short low vowels, it undergoes the glide elision rule. After application the glide elision, the two adjacent /a/ vowels are combined into the long vowel /a:/ which results in the surface representation ja-lqa: 'he meets, subjunctive case'.

As for the imperfective verbs that have non-identical stem and case vowels, a vowel assimilation rule is to be posited between the glide deletion rule and the lengthening rule to enable their derivation. This can be demonstrated by inflecting the imperfective verb ja-rmiy 'he throws' for the indicative case which produces ja-rmiy- $u$. The application of the glide elision rule to this sequence leads to the existence of the two adjacent vowels /iu/. Apparently, these two vowels are not identical and hence they cannot be contracted into a single long vowel. The /iu/ vowel cluster is not allowed because two vowels cannot occupy the same nucleus position and if each of these vowels is assumed to constitute its own syllable, then the second syllable becomes onsetless which is not allowed in Arabic. According to Mahadin (1982, 234), the /iu/ cluster undergoes a vowel assimilation rule in which the second member of the cluster assimilates to the first member. The resultant sequence, i.e. /ii/, undergoes the vowel lengthening rule and the targeted imperfective verb surfaces as ja-rmi: 'he throws, indicative case'.

\subsubsection{The Derivation of Finally-Weak APs from their Imperfective Stems}

All what is mentioned about finally-weak APs in the traditional analyses of their derivation is that their third radical, i.e. the glide, when their indefinite forms are inflected for the nominative and genitive cases (e.g. ra:min 'a thrower, nominative/genitive case') and its retained when they are inflected for the accusative case (e.g. ra:mijan 'a thrower, accusative case) (Al-Faxiri, 1996; Abd Al-Ghani, 2010; AlSamurrai, 2013; among others). These analyses tend to consider the indefinite form which is declined 
for the nominative/genitive case and has the surface pattern $\left|\mathrm{C}_{1} \mathrm{a}: \mathrm{C}_{2} \mathrm{in}\right|$ as the unmarked form of finallyweak APs. Similarly, $m u^{c} d z a m$ ?alluyah ?al ${ }^{c}$ arabijjah ?almu ${ }^{c} a$ :sirah, i.e. the dictionary from which the current corpus is compiled, uses this form as the citation form of finally-weak APs as opposed to the initially and medially weak APs which are listed in it in their uninflected, i.e. pausal, forms.

The deletion of the glide in these forms was observed by Brame (1970) who found that declining the indefinite form of finally-weak APs for the nominative or genitive case results in causing their final glide to be in a position that meets the conditions of the glide elision rule. For instance, attaching the genitive case suffix to the AP $d a:^{c} i w$ yields $d a:{ }^{c} i w-i$. The /w/ of this AP occurs between two short /i/ vowels and this prompts its deletion by the glide elision rule. The identical contiguous vowels in the resultant form, i.e. da: $i i$, are turned into the long vowel /i:/ due to the application of the vowel lengthening rule. Attaching the indefiniteness suffix /n/ to the surface form $d a:{ }^{c} i$ : derives the form $d a:{ }^{c} i$ :$n$ 'a caller'. This form undergoes a vowel shortening rule which shortens long vowels when they are followed by one consonant which occurs in the final position of the word. This rule, as presented in 19, causes the form $d a:{ }^{c} i:-n$ to surface as $d a:^{c}$ in 'a caller'.

\section{V: $\rightarrow \mathrm{V} / \_$_ $\Psi$ ( $\Psi$ designates the word boundary)}

The declination of this AP for the nominative case results in the same representation, i.e. $d a:^{c}$ in, but requires the application of the vowel assimilation rule after the glide elision (da: ${ }^{c} i j-u n \rightarrow d a:^{c} i-u n \rightarrow$ $\left.d a:{ }^{c} i i n\right)$. The removal of the indefiniteness suffix /n/ from $d a:^{c}$ in changes it to $d a:^{c} i$ : 'caller' due to its failure to meet the conditioning environment for the vowel shortening rule. Finally, similar to its imperfective base, the declension of this AP for the accusative case results in retaining its final glide (da: 'ijan 'a caller, accusative case').

It should be indicated that the derivation of the uninflected forms of finally-weak APs is generally neglected in the literature since the changes to the underlying representation of these APs are, similar to their verbal bases, assumed to be stimulated by the interaction between their stems and the suffixes that are attached to them. The analysis of the derivation of the uninflected forms of finally-weak APs requires taking a closer look at their underlying representation. The underlying representation of these APs, in the current analysis, is $\left|\mathrm{C}_{1} \mathrm{waC}_{2} \mathrm{iG}\right|$ which results from inserting the infix /wa/ between the first and second consonants of the underlying representation of their imperfective stems, which are on the pattern $\left|\mathrm{C}_{1} \mathrm{C}_{2} \mathrm{VG}\right|$, and alternating their stem vowels into /i/. The glide in the pattern $\left|\mathrm{C}_{1} \mathrm{waC}_{2} \mathrm{iG}\right|$ might be a /j/ or a $/ \mathrm{w} /$ and thus the $/ \mathrm{iG} /$ sequences are realized as /ij/ or /iw/.

These two vowel/glide sequences are not permissible diphthongs in MSA and thus they are not allowed to occur in the same syllable. The /ij/ sequence is regularly changed to /ii/ through the application of the glide, or syllabicity, assimilation process which involves the assimilation of glides to their cognate vowels when they are preceded by these vowels (cf. Brame, 1970; Abushunar \& Mahadin 2017; among others). The glide assimilation rule, as stated in 20 (a), alternates the sequences /ij/ and /uw/ into /ii/ and /uu/, respectively, when these sequences occur at the end of the word or when are followed by consonants. This rule is argued to be a natural rule that reflects the facts that Arabic does not have the /ij/ and /uw/ diphthongs and that the diphthongs that it has, i.e. /aj/ and /aw/, are not affected by this rule because the /a/ vowel does not have a cognate glide which assimilates to it. The application of this rule to the /ij/ to change it to /i:/ in the X-slot model is depicted in 20 (b). 
20. a. $\left\{\begin{array}{c}\mathrm{j} \\ \mathrm{w}\end{array}\right\} \rightarrow\left\{\begin{array}{cc}\mathrm{i} & \mathrm{i} \\ \mathrm{u} & \mathrm{i}\end{array}\right\}-\left\{\begin{array}{c}\mathrm{C} \\ \Psi\end{array}\right\}$

b.

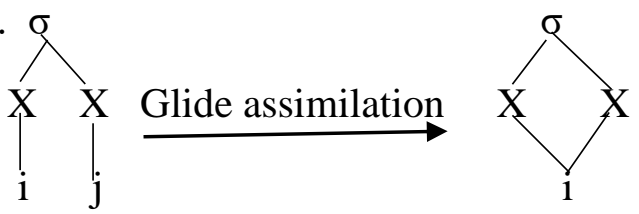

Because the stem vowel of the pattern $\left|\mathrm{C}_{1} \mathrm{waC}_{2} \mathrm{iG}\right|$ is /i/, the surface representation of the finallyweak APs that have the glide / $\mathrm{j} /$ as its last radical can be straightforwardly accounted for by the application of the glide assimilation rule. For instance, the application of this rule to rwamij, i.e. the underlying representation of the AP ra:mi: 'thrower', causes the assimilation of the $/ \mathrm{j} /$ to its cognate vowel /i/ and this yields rwamii. This sequence undergoes the vowel lengthening rule and surfaces as ra:mi: 'thrower'. As opposed to the surface representation of the finally-weak APs that end with the $/ \mathrm{j} /$, accounting for the surface representation of those that end with the /w/ cannot be done through the glide assimilation rule. This is ascribed to the fact the /w/ cannot assimilate to the /i/ in the sequence /iw/ because it is not its cognate vowel.

Since the assimilation rule cannot apply to the sequence /iw/ because its two members are phonetically dissimilar and the deletion of the first member of the sequence, i.e. the /i/, is not possible because it constitutes the nucleus of the syllable, resolving the problem of the impermissible sequencing of the /i/ and /w/ needs to target the second member which can be done in two ways. The first way is applying a rule proposed by Brame (1970) which changes the /w/ into /j/ when it is preceded by /i/ and applying the glide assimilation rule to the resultant sequence, i.e. /ij/. The other way, which is simpler and more economic, is deleting the $/ \mathrm{w} /$ and lengthening its adjacent vowel, i.e. the $/ \mathrm{i} /$, in compensation which yields /i:/. This can be exemplified in the alternation of the underlying representation $d w a^{c} i w$ to its surface representation $d a:{ }^{c} i$ : 'caller' which involves, in addition to changing the infix /wa/ into /a:/, the deletion of the $/ \mathrm{w} /$ and the lengthening of the $/ \mathrm{i} /$ in compensation as presented in 21 .

21.

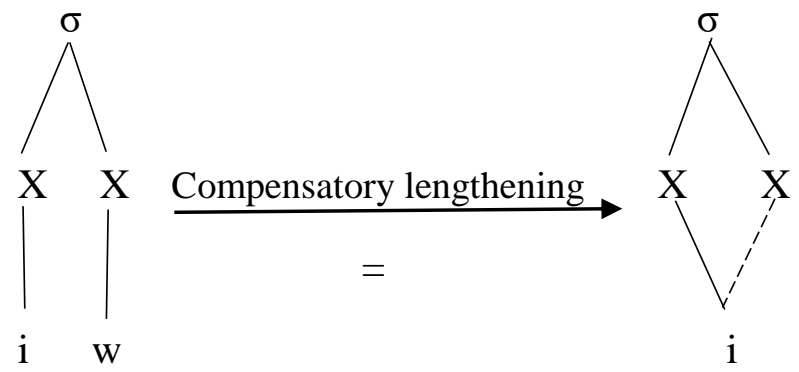

As shown in 20 (b) and in 21, glide assimilation and compensatory lengthening rules produce similar surface representations in the X-slot model of phonology. However, the latter rule is considered more general because in addition to accounting for the alternations of /ij/ and /uw/ into /i:/ and /u:/, respectively, it also straightforwardly accounts for the alternations of /iw/ and /uj/ into /i:/ and /u:/, respectively. One can add that the latter rule is mainly employed in the standard approach of phonology due its inability to account for compensatory lengthening processes. Therefore, the compensatory lengthening rule is going to be used instead of the glide assimilation to account for changing impressible diphthongs to long vowels in MSA. On the grounds that compensatory lengthening follows elision rules, the conditioning environment for the glide elision in the impressible diphthongs needs to be specified. Since the permissible diphthongs in MSA are composed of the low vowel /a/ and a glide and the impermissible ones are composed of a high vowel, i.e. /u/ or /i/, and a glide, the glide elision in the latter 
diphthongs occurs when the glide is preceded by a high vowel. Re-stating the glide assimilation rule which is given in 20 (b) as an instance of glide elision is shown in 22.

$$
\text { 22. } \mathrm{G} \rightarrow \varnothing / \mathrm{V}_{-} \underset{\left[\begin{array}{l}
\mathrm{C} \\
\Psi
\end{array}\right\}}{[\text { high] }}
$$

The conditioning environments for the all the three instances of glide elision that have been discussed so far, as stated in 8 (b), 14 and 22, are combined into one rule to form a general account of glide elision in MSA. The statement of this rule in the X-slot model of phonology is shown in 23.

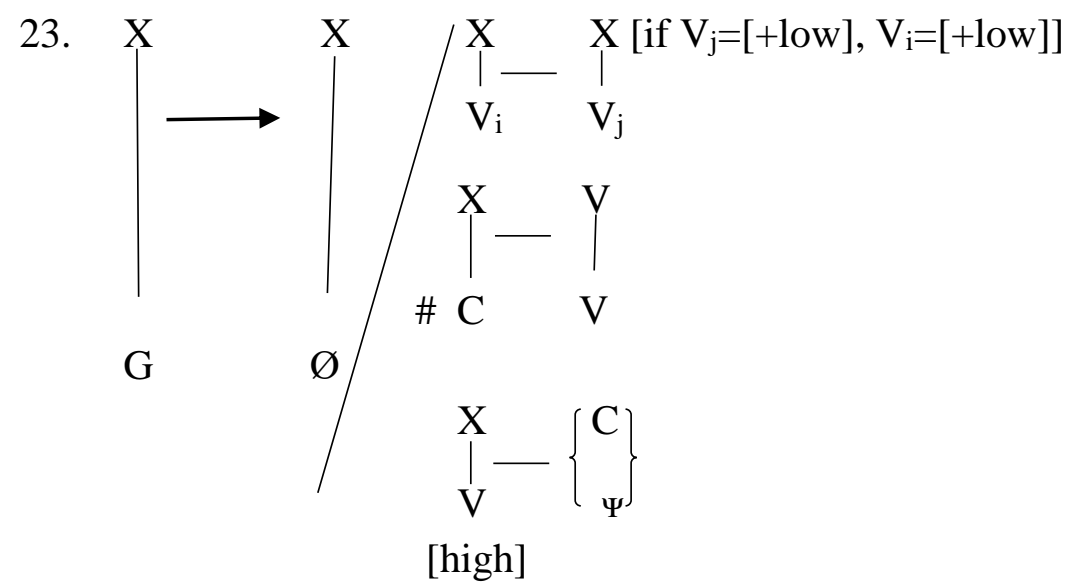

The surface representations of the 230 finally-weak APs which are listed in Appendix (C) are all of the pattern $\left|\mathrm{C}_{1} \mathrm{a}: \mathrm{C}_{2} \mathrm{in}\right|$. The representation of the derivation of these forms from their imperfective stems in the X-slot model of autosegmental phonology, ignoring the alternations of the infix /wa/ into /a:/ and of the stem vowel into /i/, is exemplified in ra:min 'a thrower, genitive case' as depicted in 24 .

24.
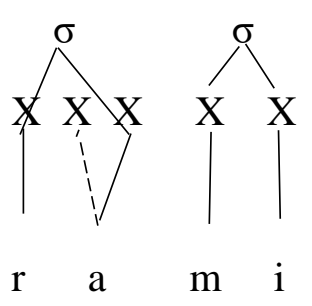

r a jo

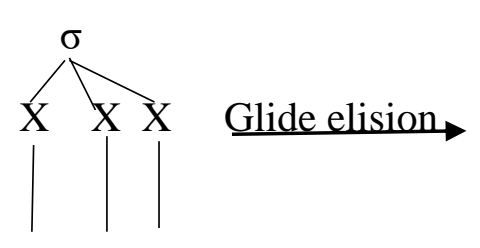

$n$

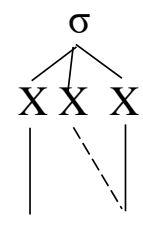

r a

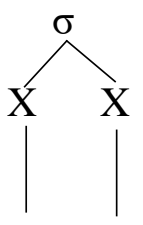

m i

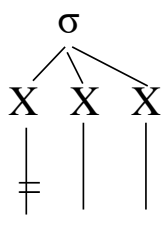

j $\quad \mathrm{i} \quad \mathrm{n}$
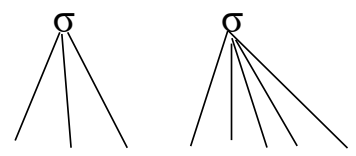

Re-syllabification

$\mathrm{X} X \mathrm{X}$
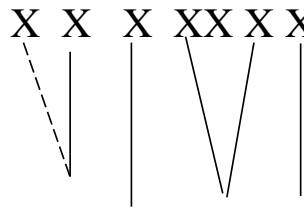

$\mathrm{r}$

a $\mathrm{m}$<smiles>[X]CCCCCC</smiles>

\section{Surface representation}
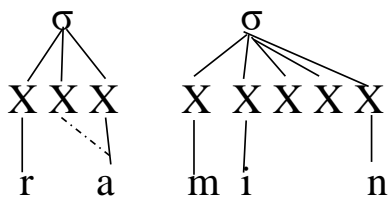
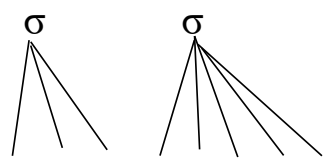

$\mathrm{X}$ X X XXXXX

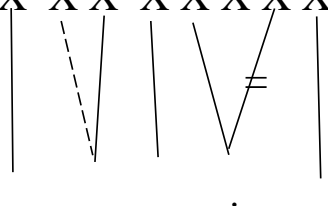

$\begin{array}{lllll}r & a & m & i & n\end{array}$ 
Two points should be indicated regarding the derivation process in 24 . The first is that if the empty $\mathrm{X}$-slot, or timing slot, is not filled by the insertion of a segment like in 17 or by the application of the compensatory lengthening process like in 18, it remains floating (cf. van der Hulst and Smith, 1982). Two instances of floating X-slots are shown in 24 . One of them results from the application of the glide elision rule to the $/ \mathrm{j} /$ and the other results from the application of the vowel shortening rule to the $/ \mathrm{i}: /$.

The second point is that when the output of a phonological rule does not conform to the constraints on syllable structures in the course of derivation, re-syllabification processes operate to re-syllabify it in accordance with these constraints (Clements \& Keyser, 1983; Mahadin, 1994). For example, the application of the glide elision rule in 24 causes the appearance of the two adjacent syllables $/ \mathrm{mi} /$ and /in/. The second syllable, i.e. /in/, is onsetless which violets MSA syllabification constraints. Accordingly, a re-syllabification rule applies and combines these two syllables into one syllable. The syllable /miin/ conforms to permissible syllable structures in MSA but it violates the OCP principle which bans adjacent identical elements at the segmental tier. Consequently, the two adjacent identical elements /ii/ are combined into the single long element /i:/ to ensure maintaining the OCP at the segmental tier.

As mentioned previously in this section, the AP surface representation ra:min is not only the result of declining ra:mi: for its genitive case but it can be also the outcome of declining this AP for its nominative case. Even though the declinations of this AP to its genitive and nominative cases yield the same surface representation, the latter case requires an extra rule, i.e. the vowel assimilation rule, to change the /iu/ sequence into /i:/. The representation of this instance of vowel assimilation rule is given in 25 .

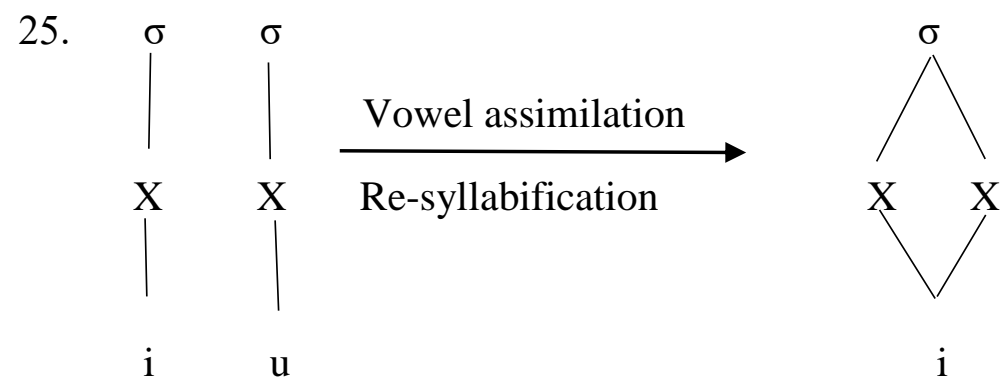

\subsection{Doubly-Weak Aps}

\subsubsection{The Imperfective Stems of Doubly-Weak Aps}

Doubly-weak imperfective stems, i.e. the stems that possess two glides in their consonantal roots, which serve as the bases for deriving doubly-weak APs in the current study are divided into two categories. The first category consists of stems which have their second and third radicals as glides, whereas the second category consists of stems which have glides as their first and third radicals. These two categories are identified by traditional grammarians as Pallafi:f Palmaqru:n 'weak stems that have adjacent glides in their consonantal roots' and Pallafi:f Palmafru:q 'weak stems that have non-adjacent glides in their consonantal roots', respectively (cf. Al-Faxiri, 1996; Abd Al-Ghani, 2010 and AlSamurrai, 2013). The former category of stems exhibits an underlying representation of the shape $\left|\mathrm{C}_{1} \mathrm{G}_{1} \mathrm{VG}_{2}\right|$ which surfaces as $\mid \mathrm{C}_{1} \mathrm{G}_{1} \mathrm{~V}$ :| (e.g. ja-lwij $\rightarrow j a$-lwi: 'he bends') and the latter has an underlying representation of the shape $\left|\mathrm{G}_{1} \mathrm{C}_{2} \mathrm{VG}_{2}\right|$ which surfaces as $\mid \mathrm{C}_{2} \mathrm{i}$ : (e.g. $j a$-w $\boldsymbol{q} \boldsymbol{i j} \rightarrow j a-\boldsymbol{q} \boldsymbol{i}$ : 'he protects').

The derivation of the surface representations of the second category from their underlying representations conforms to the regular patterns of deriving initially and finally weak verbs. That is, the glide which occurs underlyingly in the initial position of these stems is /w/ and their stem vowel is / $\mathrm{i} /$ and thus they all undergo the w-deletion rule stated in 6 (e.g. $j a-w \underline{h i j} \rightarrow j a-\underline{h} i j)$ and the glide that occurs 
underlyingly in their final position undergoes the glide elision process stated in 23 (e.g. ja- $\underline{h i j} \rightarrow j a-\underline{h} i$ : 'he inspires').

As for the stems of the first category, they follow the same derivational pattern of finally-weak verbs (e.g. ja-twij $\rightarrow j a-\underline{t} w i$ : 'he folds') but they deviate from the pattern of deriving medially-weak verbs. This is ascribed to the observation that the $|\mathrm{GV}|$ sequence in these forms fails to alternate to $|\mathrm{V}:|$ akin to its counterpart in medially-weak verbs. For instance, the $|\mathrm{GV}|$ sequence in the medially-weak verb $j a a^{c} \boldsymbol{w u} d$ surfaces as $j a-^{c} u: d$ 'he returns' but this sequence does not alternate to |V:| in the doubly-weak verb ja$r w i j$ which surfaces as ja-rwi: 'he narrates/quenches'. In this regard, Brame (1970, p. 267) stated that "the medial glide of all roots of the shape CGG is exceptional with regard to Glide Metathesis." The glide metathesis is, according to Brame (1970), the first step for deriving the surface representations of medially-weak verbs from their underlying representations (see Section 3.2.1). This rule creates an environment in which the glide assimilation and vowel lengthening rules can apply. As a result of not applying the glide metathesis rule to the doubly-weak verbs which have roots of the shape |CGG|, the conditioning environment for its subsequent rules are not met in these verbs and thus their medial glides are retained.

Allowing the imperfective verbs that have roots of the shape $\left|\mathrm{CG}_{1} \mathrm{G}_{2}\right|$ to bypass the regular derivation of medially-weak verbs can be avoided if the second conditioning environment for the glide elision rule which is stated in 14 is slightly modified. Based on this conditioning environment, the glide which is preceded by a consonant and followed by a vowel, i.e. $|\mathrm{CGV}|$, undergoes the elision rule. The elision of the glides that occur in the $|\mathbf{C G V}|$ sequence can be further restricted by proposing that the vowel in this sequence must be followed by a [consonantal] consonant. The only consonants that lack the feature [consonantal] are the glides (Spencer 1996). Thus, $\left|\mathrm{G}_{1}\right|$ in the sequence $\left|\mathrm{CG}_{1} \mathrm{VG}_{2}\right|$ does not undergo the glide elision rule because its following vowel is followed by a glide, i.e. $\left|G_{2}\right|$, lacking the [consonantal] feature.

Since the underlying form of the doubly-weak imperfective stems that have the root shape $\left|\mathrm{CG}_{1} \mathrm{G}_{2}\right|$ is $\left|\mathrm{CG}_{1} \mathrm{VG}_{2}\right|$, the glide elision rule does not apply to their medial glides. On the other hand, $\left|\mathrm{G}_{2}\right|$ in these stems meets the third conditioning environment for the glide elision rule, as stated in 23 , hence, it undergoes this rule. For example, the derivation of the surface representation of the doubly-weak verb as ja-rwi: 'he narrates/quenches' involves applying the glide elision rule to the final radical in the underling representation of its stem, i.e. rwij, and retaining its medial glide because it does not meet the conditioning environments for the glide elision rule.

\subsubsection{The Derivation of Doubly-Weak APs from their Imperfective Stems}

The 27 doubly-weak APs, which are listed in Appendix (D), exhibit derivational patterns that resemble the two categories of the imperfective bases form which they are derived. The APs that are derived from the imperfective bases of the shape $\left|G_{1} C_{2} V_{G}\right|$, akin to their imperfective bases, follow the general derivational patterns of initially and finally weak APs. Accordingly, the initial glide in these APs is retained and the final glide undergoes the elision rule. For instance, the derivation of the AP wa:qin 'a protector' from the imperfective stem wqij involves, in addition to alternating the stem vowel into /i/ and the infix /wa/ into /a:/, applying the glide elision, re-syllabification and vowel shortening rules that are stated in 24 .

On the other hand, similar to their imperfective bases, the doubly-weak APs which are derived from bases of the shape $\left|\mathrm{C}_{1} \mathrm{G}_{1} \mathrm{VG}_{2}\right|$ follow the same pattern of deriving finally-weak APs but deviate from the derivational pattern of medially-weak APs. That is, the medial $|\mathrm{G}|$ alternates to a glottal stop in mediallyweak APs (e.g. qa:wil $\rightarrow q a: P i l$ 'a teller') but this alternation does not take place in these doubly-weak verbs (e.g. ta:win $\rightarrow$ ta:win 'a folder'). According to Brame (1970), the roots of the shape $|C G G|$ are not only considered exceptions to the application of the glide metathesis rule but they are also exceptional with regard to the glottal formation rule and thus their medial glide does not alternate into |?|. 
Similar to their imperfective bases, the apparent irregularity of these AP stems can be simply accounted for by making a minor modification to the first conditioning environment for the glide elision rule which is stated in 23. Based on this conditioning environment, the glide which occurs between two vowels $|\mathrm{VGV}|$ undergoes the elision rule, except for the glides which are preceded by high vowels and followed by low vowels. The elision of the glides that occupy intervocalic positions can be further restricted by postulating that the second vowel in the $|\mathrm{VGV}|$ sequence must be followed by a [consonantal] consonant. Accordingly, $\left|\mathrm{G}_{1}\right|$ in the sequence $\left|\mathrm{VG}_{1} \mathrm{VG}_{2}\right|$ does not undergo the glide elision rule because the second vowel in this sequence is followed by a consonant which lacks the [consonantal] feature, i.e. $\left|G_{2}\right|$. The underlying representation of the doubly-weak APs which have the root $|\mathrm{CGG}|$ is $\left|\mathrm{CwaG}_{1} \mathrm{iG}_{2} \mathrm{in}\right| .\left|\mathrm{G}_{1}\right|$ in this representation is preceded by the vowel /a/ and followed by the vowel/i/ which in turn is followed by $\left|\mathrm{G}_{2}\right|$. Therefore, the glide elision does not target $\left|\mathrm{G}_{1}\right|$ because it does not meet the first conditioning environment for this rule.

The restatement of the glide elision rule in 4.19 with the modifications to the its first and second conditioning environments, which are made in Sections 3.4.2 and 3.4.1, respectively, is shown in 26.

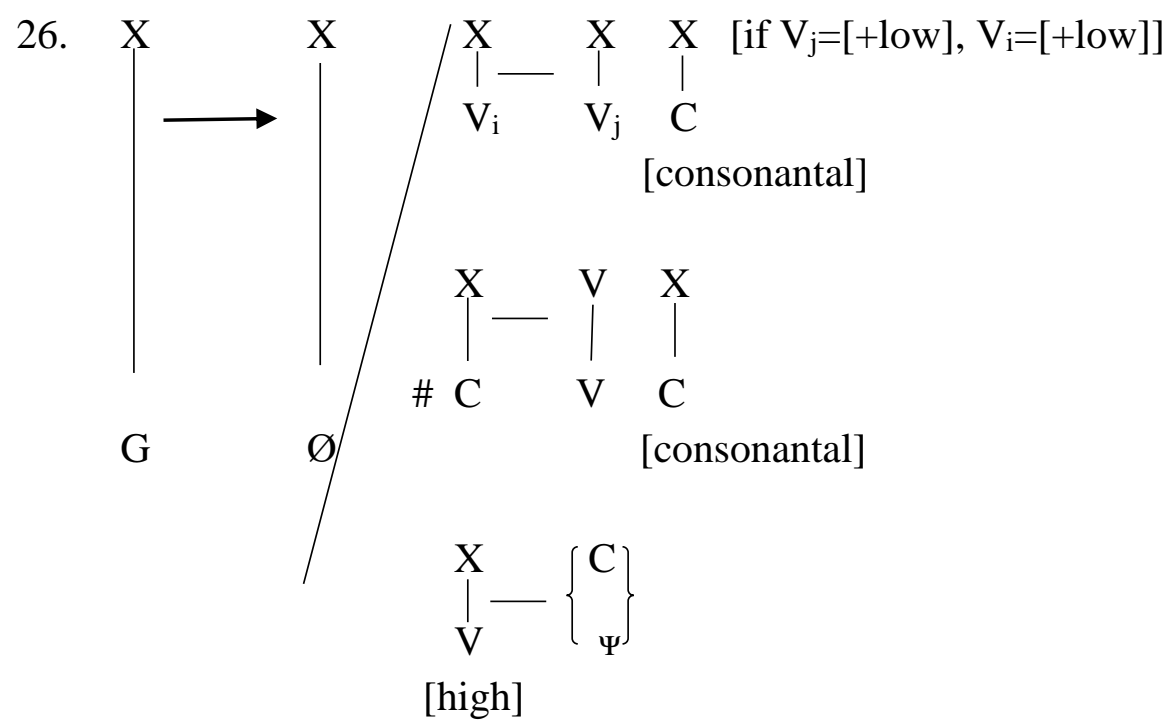

\section{Conclusions}

The analysis of the current AP corpus reveals that the derivation of initially-weak APs from their imperfective bases involves no additional processes to the ones employed for the derivation of their strong counterparts. On the other hand, the medially, finally and doubly weak APs undergo, in addition to the process that derive strong APs, the glide elision rule which is followed by compensatory lengthening, re-syllabification and insertion processes. Accounting for these processes is only possible in the X-slot model of autosegmental phonology due to its reference to the quantity of segments independently of their quality and to it utilization of a purely phonological unit, viz. the syllable, for the statement of phonological rules.

\section{Ethics Committee Approval}

The author(s) confirm(s) that the study does not need ethics committee approval according to the research integrity rules in their country (Date of Confirmation: October 22, 2020). 


\section{References}

Abd Al-Ghani, A. (2010). Passarf Palka:fi: [sufficient morphology]. Cairo: da:r Pttawfi:qijjah liltura: $\theta$.

Abdo, D. (2008). ?abha: $\theta$ fi: Palkalimah wa Padzumlah [studies in the word and the sentence]. Amman: da:r Palkarmil.

Abdo, D. (2010). dira:sa:t fi: ${ }^{c} i l m$ Paswa:t Pal ${ }^{c}$ arabijjah [studies in Arabic phonology]. (VOL 2). Amman: da:r dzari:r.

Abu Salim, I. (1988). On the phonological status of /?/ in Classical Arabic. Albahth, 36, 71-79.

Abushunar, M. and Mahadin, R. (2017). An autosegmental analysis of Arabic passive participle of triliteral verbs, Arab Society of English Language Studies, 8, 252-267.

Al-Faxiri, S. (1996). taśri:f PalPf a:l wa Palmaśa:dir wa Palmuftaqqa:t [the inflection of verbs, verbal nouns and derived forms]. Cairo: ${ }^{\mathrm{c} a s m i}$ liPannafir wa Pattwzi: ${ }^{\mathrm{c}}$.

Al-Nuri, J. (2007). ${ }^{c} i l m$ PalPaswa:t Pal ${ }^{c}$ arabijjah [Arabic phonology]. Palestine: dza:micat Palquds Palmaftu:hah.

Al-Raajihi, A. (1984). Pattatbiiq Passarfi: [morphological application]. Beirut: da:r Pannahd Palcarabijjah.

Al-Samurrai, M. (2013). Passarf Pal'arabij Pahka:m wa maca:ni: [the rules and meanings of Arabic morphology]. Sharjah: da:r Pibin kaӨi:r.

Alshdaifat, A. (2014). The formation of nominal derivatives in the Arabic language with a view to computational linguistics (Unpublished Doctoral dissertation), University of Salford, Salford.

Aniis, I. (1975). Pal Paswa:t Palluyawijjih [Arabic sounds]. Cairo: maktabat al Pa:nglo Palmasirijjah.

Benmamoun, E. (1999). Arabic morphology: The central role of the imperfective. Lingua, 108,175201

Clements, G \& Keyser, S. (1983). CV phonology: A generative theory of the syllable. Cambridge: The MIT Press.

Goldsmith, J. (1976). An overview of autosegmental phonology. Linguistic Analysis, 2, 23-68.

Hayes, B. (1989). Compensatory lengthening in moraic phonology. Linguistic Inquiry, 20, 253-306.

Hetzron, R. (1992). Semitic languages. In W. Bright (Ed.), International Encyclopedia of Linguistics (pp. 412-417). Oxford: Oxford University Press.

Holes, C. (1995). Modern Arabic: Structures, functions and varieties. London: Longman.

Hulst, H. \& Smith, N. (1982). An overview of autosegmental and metrical phonology. In H. Hulst, H. \& N. Smith (Ed.), The structure of phonological representations (pp.2-45). Dordrecht: Foris Publications.

Ibin Asfor, A. (1987). Plmumtic fi: Pttas rii:f [enjoyable morphology] (Vol. 1). Beirut: da:r Plmacrifah.

Ibin Jinni, A. (1954), Palmunsif [the equitable] (Vol. 2). Cairo: da:r Pihaja:? Pattura: $\theta$ Palqadi:m.

Kenstowicz, M. (1994). Phonology in generative grammar. Cambridge, Mass. \& Oxford: Blackwell.

Levy, M. (1971). The plural of the noun in Modern Standard Arabic. Ph.D. dissertation, University of Michigan. 
Mahadin, R. (1982). The morphophonemics of the standard Arabic triconsonantal verbs. Unpublished Doctoral Dissertation, University of Pennsylvania, Philadelphia.

Mahadin, R. (1994). An X-skeleton of some phonological processes in Arabic. Al-Abhath, 42, 49-95.

McCarthy, J. (1982). Nonlinear phonology: An Overview. GLOW Newsletter. 50. Retrieved August 23, 2019 from https://scholarworks.umass.edu/linguist_faculty_pubs/50

McCarthy, J. (1994). The phonetics and phonology of Semitic pharyngeal. In P. Keating (Ed.), Phonological Structure and Phonetic Forms (pp. 191-233). Cambridge: Cambridge University Press.

Omar, A. (2008). mucdzam Palluyah Pal'arabijjah Palmu'aasirah [the dictionary of Modern Standard Arabic]. Cairo: 'aalam alkutub.

Ryding, K. (2005). A reference grammar of modern standard Arabic. Cambridge: Cambridge University Press.

Shahin, A. (1980). Palmanhadz Pssawti lilbunjah Palcarabijjah [a phonological analysis to Arabic structure]. Beirut: Parrisa:lah.

Spencer, A. (1996). Phonology: Theory and description. Oxford: Blackwell.

Sibawayh, A. (1982). Palkita:b [the book] (Vol. 4). ${ }^{c} a: l a m$ Palkutub wa Pattiba: ${ }^{c}$ ah wa Pannafir: Beirut.

Watson, J. (2002). The phonology and morphology of Arabic. Oxford: Oxford University Press.

Wright, W. (1896). A grammar of the Arabic language. Cambridge: Cambridge University Press

Żygis, M. (2010). Typology of consonantal insertions. ZAS Papers in Linguistics, 52, 111-40.

\section{Appendix A. An example appendix}

Table 5. Initially-Weak APs of the Pattern $\mathrm{C}_{1} \mathrm{a}: \mathrm{C}_{2} \mathrm{C}_{3}$

\begin{tabular}{|c|c|c|c|}
\hline Number & $\begin{array}{l}\text { Dictionary } \\
\text { entry } \\
\text { number }\end{array}$ & Gloss & $\begin{array}{l}\text { Active } \\
\text { participle }\end{array}$ \\
\hline 1 & 5525 & to bury alive & waizid \\
\hline 2 & 5527 & to agree with & swa:Zims \\
\hline 3 & 5539 & to perish & waibia \\
\hline 4 & 5539 & to perish & swaibia \\
\hline 5 & 5540 & $\begin{array}{l}\text { to rain } \\
\text { heavily }\end{array}$ & swa;bil \\
\hline 6 & 5540 & $\begin{array}{l}\text { to have bad } \\
\text { consequences }\end{array}$ & swaibil \\
\hline 7 & 5541 & to wedge & wastid \\
\hline 8 & 5542 & to hold back & watis \\
\hline 9 & 5545 & to jump & swa:eib \\
\hline 10 & 5547 & to trust & waieiq \\
\hline 11 & 5548 & to settle & swa:ein \\
\hline 12 & 5499 & $\begin{array}{l}\text { to fall down } \\
\text { to be } \\
\text { imperative } \\
\text { to have a } \\
\text { meal } \\
\text { to beat } \\
\text { rapidly }\end{array}$ & wa:dsib \\
\hline 13 & 5550 & $\begin{array}{l}\text { to be sad for } \\
\text { to adore } \\
\text { to hate } \\
\text { to come } \\
\text { across } \\
\text { to have } \\
\text { money } \\
\text { to know }\end{array}$ & swa:dsid \\
\hline
\end{tabular}

\begin{tabular}{|c|c|}
\hline to settle down & wa:dic \\
\hline to leave & swa:Dir. \\
\hline to inherit & wsa:rie \\
\hline to arrive & swa:rid. \\
\hline to expand & swarrif \\
\hline to put forth & warria. \\
\hline leaves & 3acostes. \\
\hline $\begin{array}{l}\text { to have large } \\
\text { hips }\end{array}$ & swa:rik. \\
\hline $\begin{array}{l}\text { to become } \\
\text { swollen }\end{array}$ & jwarrims \\
\hline to $\sin$ & swa:zir \\
\hline to stop & yxa:zic \\
\hline to weigh & wra:zin \\
\hline to be centered & swa:sit \\
\hline to expand & wassic \\
\hline to encompass & 3wa:sic \\
\hline to envelop & ywasia \\
\hline to need & wa:sil \\
\hline to mark & wassim. \\
\hline to intertwine & swa: كtds \\
\hline to tattoo & was:fims \\
\hline $\begin{array}{l}\text { to be } \\
\text { consistent }\end{array}$ & warsib \\
\hline to describe & wa:sif \\
\hline $\begin{array}{l}\text { to arrive } \\
\text { to connect } \\
\text { to treat good }\end{array}$ & sxa:sil \\
\hline
\end{tabular}




\begin{tabular}{|c|c|c|c|c|c|c|c|}
\hline 14 & 5551 & to be brief & wa:dziz & 45 & 5620 & to disgrace & wa:sim \\
\hline \multirow[t]{2}{*}{15} & 5552 & to be hidden & wa:dzis & 46 & 5624 & to be clear & wa;dih \\
\hline & & to fear & & 47 & 5625 & to put & wa:dic \\
\hline 16 & 5554 & to hurry up & wa:dzif & & & to humiliate & \\
\hline \multirow[t]{2}{*}{17} & 5556 & to be & wa:dzim & & & to deprive & \\
\hline & & speechless & & 48 & 5626 & to put on the & wa:dim \\
\hline \multirow[t]{2}{*}{18} & 5558 & to hit one's & wa:dzith & & & cutting board & \\
\hline & & face & & 49 & & & \\
\hline 19 & 5559 & to be alone & wa:hid & 50 & 5627 & to weave & wa:din \\
\hline 20 & 5565 & to pierce & waxiz & 51 & 5628 & to be simple & waiti? \\
\hline \multirow[t]{2}{*}{21} & 5566 & to become & wa;xit & 52 & 5632 & $\begin{array}{l}\text { to step } \\
\text { to break }\end{array}$ & watis \\
\hline & 5571 & $\begin{array}{l}\text { gray-haired } \\
\text { to leave }\end{array}$ & wa: $\mathrm{di}^{\mathrm{c}}$ & 53 & 5634 & to inhabit & watin \\
\hline 54 & & & & 78 & 5676 & to delegate & wa:kil \\
\hline \multirow[t]{2}{*}{55} & 5636 & to be & wa:gib & 79 & 5678 & to decrease & wa-lit \\
\hline & & persistent & & 80 & 5679 & to enter & wa:lidz. \\
\hline 56 & 5638 & to collect & wa-cib & 81 & 5680 & to give birth & wa:lid \\
\hline \multirow[t]{2}{*}{57} & 5640 & to promise & wa-cid & 82 & 5682 & to drink & wa:lix \\
\hline & & to threaten & & 83 & 5685 & to grieve & wa:lih \\
\hline 58 & 5641 & to be bumpy & wa-cis & 84 & 5685 & to grieve & wa:lih \\
\hline 59 & 5642 & to designate & wa-ciz & 85 & 5688 & to indicate & waimi? \\
\hline 60 & 5643 & to preach & wa-cid & 86 & 5690 & to twinkle & \\
\hline 61 & 5644 & to be in pain & wa-cik & 87 & 5694 & to bestow & wa:hib \\
\hline \multirow[t]{2}{*}{62} & 5648 & to be filled & wayir. & 88 & 5695 & to inflame & wa:hids \\
\hline & & with hatred & & 89 & 5698 & to imagine & wa:him \\
\hline 63 & 5648 & $\begin{array}{l}\text { to be filled } \\
\text { with hatred }\end{array}$ & wayst & 90 & 5698 & to be & wa:him \\
\hline \multirow[t]{4}{*}{64} & 5649 & to intrude & wayil & & & delusional & \\
\hline & & upon & & 91 & 5699 & to be weak & wa:hin \\
\hline & & to delve into & & 92 & 5699 & to weaken & wa:hin \\
\hline & & & & 93 & 5709 & to lose hope & ja:?is \\
\hline \multirow{2}{*}{$\begin{array}{l}65 \\
66\end{array}$} & 5651 & to arrive at & wa:fid & 94 & 5724 & to be dry & ja:bis \\
\hline & 5652 & to increase & wa:fir & 95 & 5739 & to become & jasisir \\
\hline \multirow{2}{*}{$\begin{array}{l}67 \\
68\end{array}$} & 5654 & to be right & wa:fia & & & easy & \\
\hline & 5656 & to darken & wa:gib & & & to be rich & \\
\hline \multirow{2}{*}{$\begin{array}{l}69 \\
--\end{array}$} & 5657 & to time & wa:git & & & $\begin{array}{l}\text { to dispense } \\
\text { with }\end{array}$ & \\
\hline & 5650 & - & & & & & \\
\hline $\begin{array}{l}70 \\
71\end{array}$ & $\begin{array}{l}5659 \\
5661\end{array}$ & $\begin{array}{l}\text { to inflame } \\
\text { to be deaf }\end{array}$ & wa:9ad & 96 & 5739 & to become & iassir. \\
\hline \multirow{4}{*}{72} & 5601 & $\begin{array}{l}\text { to be deaf } \\
\text { to happen }\end{array}$ & $\begin{array}{l}\text { wa:gat } \\
\text { waroic }\end{array}$ & & & easy & \\
\hline & & $\begin{array}{l}\text { to nappen } \\
\text { to appear }\end{array}$ & watas & 97 & 5743 & to shout & ia is \\
\hline & & to fall & & 98 & 5749 & $\begin{array}{l}\text { to hit on the } \\
\text { fontanelle }\end{array}$ & ia:fix \\
\hline & 5664 & to insult & waraif & 99 & 5750 & to be young & iajfic \\
\hline \multirow{2}{*}{73} & 2004 & $\begin{array}{l}\text { to stand up } \\
\text { to inform }\end{array}$ & wersis & 100 & 5757 & to make & iasmin \\
\hline & 5671 & $\begin{array}{l}\text { to stop } \\
\text { to nest }\end{array}$ & wa:kir. & 101 & 5757 & $\begin{array}{l}\text { blessed } \\
\text { to turn right }\end{array}$ & iasmin \\
\hline 75 & 5672 & to hit & wa:kiz & & & & \\
\hline 76 & 5673 & to decrease & wa:kis. & & & & \\
\hline 77 & 5675 & to flow & wa:kif & & & & \\
\hline
\end{tabular}


Appendix (B)

Table 6. Medially-Weak APs of the Pattern $\mathrm{C}_{1} \mathrm{a}: \mathrm{C}_{2} \mathrm{iC}_{3}$

\begin{tabular}{|c|c|c|c|}
\hline Number & $\begin{array}{l}\text { Dictionary } \\
\text { entry } \\
\text { number }\end{array}$ & Gloss & $\begin{array}{l}\text { Active } \\
\text { participle }\end{array}$ \\
\hline 1 & 804 & to deserve & ba:-2in \\
\hline 2 & 812 & to reveal & ba:2ih \\
\hline 3 & 813 & $\begin{array}{l}\text { to become } \\
\text { silly }\end{array}$ & ba:?ix \\
\hline 10 & 871 & to lay eggs & ba-2id \\
\hline 11 & 873 & to sell & ba: $2 \mathrm{ic}^{\mathrm{c}}$ \\
\hline 12 & 879 & $\begin{array}{l}\text { to appear } \\
\text { to leave }\end{array}$ & ba:-2in \\
\hline 13 & 1006 & to repent & ta: $3 i b$ \\
\hline 14 & 1013 & to long & ta-2id \\
\hline 15 & 1018 & to get lost & ta: 3 ih \\
\hline 16 & 1022 & $\begin{array}{l}\text { to make } \\
\text { possible for }\end{array}$ & ta: ih \\
\hline 17 & 1029 & to be in love & ta: 3 im \\
\hline 18 & 1031 & to get lost & $\mathrm{ta}: 3 \mathrm{ih}$ \\
\hline 19 & 1079 & $\begin{array}{l}\text { to come back } \\
\text { to one's } \\
\text { senses }\end{array}$ & $\theta \mathrm{a}: 2 \mathrm{ib}$ \\
\hline 20 & 1080 & to rebel & धa:Zis \\
\hline 21 & 1261 & to wander & dza:izib \\
\hline 22 & 1264 & $\begin{array}{l}\text { to exist in } \\
\text { large numbers } \\
\text { or amounts }\end{array}$ & dzaizid \\
\hline 23 & 1267 & to be unjust & dza:iar \\
\hline 24 & 1269 & to be accepted & dza-iziz \\
\hline 25 & 1270 & $\begin{array}{l}\text { to keep } \\
\text { coming back }\end{array}$ & dza-iis \\
\hline 26 & 1271 & to be hungry & dza $3 i^{c}$ \\
\hline 27 & 1275 & to roam & dza:3it \\
\hline 28 & 1282 & to occur & dzaisin \\
\hline 29 & 1287 & to quake & dzaisid \\
\hline 30 & 1288 & to rot & dza-ifif \\
\hline 31 & 1497 & to $\sin$ & ha:-2ib \\
\hline 32 & 1500 & to keep & ha:-2id \\
\hline 33 & 1501 & to come back & ha:-2ir \\
\hline 34 & 1502 & to possess & ha:-2iz \\
\hline 35 & 1503 & to stop & ha:2if \\
\hline 36 & 1507 & to guard & ha-2it \\
\hline 37 & 1510 & to contrive & ha-2iks \\
\hline 38 & 1511 & $\begin{array}{l}\text { to elapse } \\
\text { to stop }\end{array}$ & ha:?il \\
\hline 39 & 1513 & $\begin{array}{l}\text { to move in } \\
\text { circles }\end{array}$ & ha:-3im \\
\hline 40 & 1518 & $\begin{array}{l}\text { to alter one's } \\
\text { course }\end{array}$ & ha:-2id \\
\hline 41 & 1519 & $\begin{array}{l}\text { to be } \\
\text { confused }\end{array}$ & ha:?ir \\
\hline 42 & 1520 & to possess & ha:-2iz \\
\hline 43 & 1523 & $\begin{array}{l}\text { to try to } \\
\text { escape }\end{array}$ & ha:?is \\
\hline
\end{tabular}

\begin{tabular}{|c|c|c|c|}
\hline 4 & 817 & $\begin{array}{l}\text { to leave } \\
\text { uncultivated }\end{array}$ & ba:2ir \\
\hline 5 & 822 & to kiss & ba-Zis \\
\hline 6 & 829 & to sell & $\mathrm{ba}-2 \mathrm{ic}$ \\
\hline 7 & 834 & to urinate & ba-zil \\
\hline 8 & 850 & to become & ba-2it \\
\hline 9 & 855 & to diminish & ba:-2id \\
\hline 44 & 1524 & to menstruate & ha-Zid \\
\hline 45 & 1526 & to be unfair & ha:-2if \\
\hline 46 & 1527 & to confine & ha:-2iq \\
\hline 47 & 1528 & to weave & ha-2iks \\
\hline 48 & 1529 & to change & ha:?i1 \\
\hline 49 & 1530 & to approach & ha-Zin \\
\hline 50 & 1703 & $\begin{array}{l}\text { to roar } \\
\text { to become } \\
\text { weaker }\end{array}$ & xa-2ir \\
\hline 51 & 1705 & to go through & $x a-2 i d$ \\
\hline 52 & 1706 & to be scared & $x a-2$ if \\
\hline 53 & 1708 & to betray & $x a:$ in \\
\hline 54 & 1710 & to fail & $x a-2 i b$ \\
\hline 55 & 1711 & to pick & $\mathrm{xa} \cdot \mathrm{Zir}$ \\
\hline 56 & 1715 & to sew & xa-2it \\
\hline 57 & 1716 & $\begin{array}{l}\text { to be arrogant } \\
\text { to assume }\end{array}$ & xa:2i1 \\
\hline 58 & 1882 & to feel dizzy & da-2ix \\
\hline 59 & 1884 & $\begin{array}{l}\text { to keep } \\
\text { moving in } \\
\text { circles }\end{array}$ & da-Zir \\
\hline 60 & 1887 & to step on & da-Zis \\
\hline 61 & 1892 & to be changed & da:-2il \\
\hline 62 & 1896 & to persist & da:Zim \\
\hline \multirow[t]{2}{*}{63} & 1898 & to be & da-Zin \\
\hline & & despicable & \\
\hline 64 & 1922 & to borrow & da:-2in \\
\hline 65 & 1984 & to melt & Qa-2ib \\
\hline 66 & 1985 & to prevent & Ca:-2id \\
\hline 67 & 1986 & to experience & 6a-2iq \\
\hline 68 & 1993 & $\begin{array}{l}\text { to be } \\
\text { widespread }\end{array}$ & $8 \mathrm{a}: 2 \mathrm{i}^{\mathrm{c}}$ \\
\hline 69 & 1994 & to have a tail & aa-2il \\
\hline 70 & 2216 & $\begin{array}{l}\text { to make } \\
\text { skeptical }\end{array}$ & rairib \\
\hline 71 & 2218 & to drop dung & raizie \\
\hline 72 & 2219 & to be current & raizidz \\
\hline 73 & 2220 & to leave & raizin \\
\hline 74 & 2220 & $\begin{array}{l}\text { to feel } \\
\text { comfortable }\end{array}$ & raitih \\
\hline 75 & 2221 & to lead & raitid. \\
\hline 76 & 2228 & to train & raitid \\
\hline 77 & 2229 & to be scared & rairi $i^{c}$ \\
\hline 78 & 2230 & to elude & raitix \\
\hline 79 & 2231 & to be pure & raizia \\
\hline 80 & 2234 & to aspire to & raitima \\
\hline
\end{tabular}




\begin{tabular}{|c|c|c|c|c|c|c|c|}
\hline \multirow[t]{2}{*}{81} & \multirow[t]{2}{*}{2243} & \multirow{2}{*}{$\begin{array}{l}\text { to make } \\
\text { skeptical }\end{array}$} & \multirow[t]{2}{*}{ ra:iaib } & \multicolumn{2}{|c|}{$\begin{array}{ll}119 & 2921\end{array}$} & \multirow{2}{*}{$\begin{array}{l}\text { to kick } \\
\text { to see }\end{array}$} & \multirow{2}{*}{$\begin{array}{l}\text { fa:?it } \\
\text { fa:?if }\end{array}$} \\
\hline & & & & 120 & 2923 & & \\
\hline 82 & 2244 & to slow down & ra: $2 i \theta$ & 121 & 2925 & to yearn & faipig \\
\hline 83 & 2246 & to smell & raizih & 122 & 2926 & to become & fariak \\
\hline \multirow[t]{2}{*}{84} & 2247 & to have & raizic & & & strong & \\
\hline & & feathers & & 123 & 2926 & to be pierced & fariik \\
\hline 85 & 2248 & to increase & rairita & & & with a thorn & \\
\hline 86 & 2250 & to be poured & ra:iig & 124 & 2928 & to become & Sa:itil \\
\hline 87 & 2252 & to depart & raitim & & & high & \\
\hline 88 & 2253 & to cover & ra:itin & 125 & 2931 & to be ugly & farifh \\
\hline 89 & 2370 & to run & za:?id & 126 & 2938 & to build & faid \\
\hline 90 & 2373 & to dislocate & za: i ih & 127 & 2941 & to burn & far $\{$ it \\
\hline \multirow[t]{2}{*}{91} & 2374 & to prepare & za:iid & 128 & 2943 & to spread & faria \\
\hline & & supplies & & 129 & 2947 & to pick up & far $\{\mathrm{it}$ \\
\hline 92 & 2375 & to visit & za:?ir & 130 & 2949 & to disgrace & faritin \\
\hline 93 & 2377 & to be removed & $z a i 2 a^{c}$ & 131 & 3073 & to be correct & sa:iib \\
\hline 94 & 2378 & to deviate & za:?iv & 132 & 3074 & to yell & saipit \\
\hline \multirow{2}{*}{95} & 2382 & to cease to & za:iail & 133 & 3078 & to direct & saipir \\
\hline & & exist & & 134 & 3079 & to measure & sa: $2 i^{\mathrm{c}}$ \\
\hline 96 & 2383 & to get angry & za:iim & 135 & 3080 & to mold & sa: $2 \mathrm{ix}$ \\
\hline 97 & 2386 & to oil & za:2it & 136 & 3082 & to assault & sa:2it \\
\hline 98 & 2390 & to disappear & za: inh & 137 & 3085 & to fast & sa:iim \\
\hline 99 & 2391 & to increase & za:iid. & 138 & 3087 & to protect & sa: in \\
\hline \multirow[t]{2}{*}{10} & 2394 & to become & za:?it & 139 & 3089 & to scream & saitih \\
\hline & & noisy & & 140 & 3090 & to hunt & saitid \\
\hline 10 & 2395 & to swerve & za:idiv & 141 & 3092 & to become & saitir \\
\hline 10 & 2396 & $\begin{array}{l}\text { to act in a } \\
\text { dishonest way }\end{array}$ & $z a: ?$ if & 142 & 3095 & $\begin{array}{l}\text { to stay in the } \\
\text { summer }\end{array}$ & sa:?if \\
\hline 10 & 2399 & to beautify & za:? in & 143 & 3151 & to be & da:- in \\
\hline \multirow[t]{2}{*}{10} & 2667 & to prevail & saipid & & & lightened up & \\
\hline & & & & 144 & 3152 & to be hungry & da: 2 ir \\
\hline 105 & 2669 & to get angry & sa:?ir & 145 & 3154 & to smell good & da: $2 \mathrm{i}^{\mathrm{c}}$ \\
\hline 106 & 2670 & to rule & satitis & 146 & 3156 & to harm & da:-2ir \\
\hline 107 & 2672 & to lash & saitit & 147 & 3158 & to be lost & da: $2 \mathrm{i}^{\mathrm{c}}$ \\
\hline \multirow[t]{2}{*}{108} & 2673 & to be & saitix & 148 & 3159 & to host & da: 2 if \\
\hline & & permitted & & 149 & 3160 & to be narrow & da:-2iq \\
\hline 109 & 2677 & to lead & sa:iig & 150 & 3161 & to be unjust & da:?im \\
\hline 110 & 2678 & to rub & sa:iik & 151 & 3252 & to go astray & ta: 3 ih \\
\hline 111 & 2682 & to wander & sa:itim & 152 & 3258 & to obey & taicic \\
\hline 112 & 2687 & to flow & sa:itib & 153 & 3259 & to go around & taijif \\
\hline \multirow[t]{2}{*}{113} & 2692 & to flow & sa:ith & 154 & 3260 & to bear & ta:?ig \\
\hline & & to cruise & & 155 & 3261 & to reach & ta:3it \\
\hline 114 & 2693 & to sink & sa:iix & 156 & 3294 & to go astray & ta: 2 ih \\
\hline 115 & 2695 & to walk & sa:itir & 157 & 3265 & to fly & ta:?ir \\
\hline 116 & 2703 & to taste good & sa:ixix & 158 & 3266 & to be headless & ta:3if \\
\hline 117 & 2707 & to stream & sa:iit & 159 & 3267 & to obey & ta: $3 \mathrm{c}$ \\
\hline 118 & 2916 & to blemish & farib & 160 & 3268 & to go around & ta:3if \\
\hline
\end{tabular}




\begin{tabular}{|c|c|c|c|c|c|c|c|}
\hline & \multirow{2}{*}{\multicolumn{2}{|c|}{3916}} & \\
\hline \multirow{3}{*}{$\begin{array}{l}161 \\
162\end{array}$} & \multirow{3}{*}{$\begin{array}{l}3269 \\
3271\end{array}$} & \multirow{3}{*}{$\begin{array}{l}\text { to bear } \\
\text { to throw mud } \\
\text { at }\end{array}$} & \multirow{3}{*}{$\begin{array}{l}\text { ta: } 19 \\
\text { ta: } 2 \text { in }\end{array}$} & & & to be filled & fairid \\
\hline & & & & & & with & \\
\hline & & & & 198 & 4129 & to feed & ga-2it \\
\hline 163 & 3489 & to contort & a:jidz & 199 & 4131 & to lead & ga:-2id \\
\hline 164 & 3490 & to return & saisid & 200 & 4133 & to measure & ga:?is \\
\hline \multirow{2}{*}{165} & \multirow{2}{*}{3491} & to seek & \multirow[t]{2}{*}{ caijid } & 201 & 4134 & to demolish & ga:-2id \\
\hline & & protection & & 202 & 4137 & to follow & ga: 2 if \\
\hline 166 & 3493 & to miss & $\mathrm{ca} ; \mathrm{iz}$ & 203 & 4138 & to cackle & ga:2iq \\
\hline 167 & 3496 & to compensate & a:jid & 204 & 4141 & to speak & ga:2il \\
\hline 168 & 3497 & to be stopped & ca:iag & 205 & 4145 & to stand up & ga:-2im \\
\hline 169 & 3498 & to be unjust & ca:itit & 206 & 4148 & to vomit & ga:-2in \\
\hline 170 & 3500 & to float & ca:iim & 207 & 4151 & to tie & ga:-zid \\
\hline 171 & 3504 & to disfigure & a $;: ; i b$ & 208 & 4154 & to measure & ga:?is \\
\hline 172 & 3505 & to ravage & ca:ie & 209 & 4158 & to crack & ga:-2id \\
\hline 173 & 3506 & to disgrace & cajis & 210 & 4159 & to become hot & ga:2id \\
\hline 174 & 3510 & to hate & a: 3 if & 211 & 4160 & to crackle & qa:-2iq \\
\hline 175 & 3511 & to stop & cairia & 212 & 4161 & to nap & qa:2i1 \\
\hline 176 & 3512 & $\begin{array}{l}\text { to become } \\
\text { poor }\end{array}$ & caisit & 213 & 4451 & $\begin{array}{l}\text { to drink from } \\
\text { a jug }\end{array}$ & $\mathrm{ka}: 2 \mathrm{iz}$ \\
\hline 177 & 3625 & to fall in & ya:-?ir. & 214 & 4473 & to exist & $\mathrm{ka}: 2$ in \\
\hline 178 & 3628 & to dive & ya:?is & 215 & 4480 & to deceive & ka:-2id \\
\hline 179 & 3629 & to $\operatorname{sink}$ & ya-2it & 216 & 4487 & to weigh & ka:2il \\
\hline 180 & 3631 & to destroy & ya:-2il & 217 & 4494 & to be weak & $\mathrm{ka} \cdot 2$ in \\
\hline \multirow[t]{6}{*}{181} & \multirow[t]{6}{*}{3633} & to speak ill of & \multirow{6}{*}{ ya:-2ib } & 218 & 4641 & to dirty & $1 \mathrm{a}-3 \mathrm{i \theta}$ \\
\hline & & somebody & & 219 & 4644 & to appear & la: 3 ih \\
\hline & & to fall into a & & 220 & 4645 & to escape & la:iid \\
\hline & & coma & & 221 & 4649 & to ask for & la; $; i z$ \\
\hline & & to absent & & & & protection & \\
\hline & & oneself from & & 222 & 4651 & to cling to & la: 2 it \\
\hline 182 & 3634 & to help & ya:2ie & & & to be gay & \\
\hline 183 & 3636 & to be jealous & ya:?ir & 223 & 4653 & to be & la: $3 i^{c}$ \\
\hline 184 & 3637 & to disappear & ya:-2id & & & impatient & \\
\hline 185 & 3638 & to sink & ya:-2it & 224 & 4655 & to chew & $1 \mathrm{a}-2$ if \\
\hline 186 & 3639 & to enrage & ya:-2id & 225 & 4656 & to chew & la:3iks \\
\hline 187 & 3642 & to harm & ya:-2i1 & 226 & 4660 & to blame & la: $2 \mathrm{im}$ \\
\hline 188 & 3643 & to be cloudy & ya:-2im & 227 & 4666 & to deprive & la:-3it \\
\hline 189 & 3872 & to pass & faifit & & & from & \\
\hline \multirow[t]{2}{*}{190} & \multirow[t]{2}{*}{3879} & to spread a & \multirow[t]{2}{*}{ fairith } & 228 & 4675 & to be fit for & 1a:3ig \\
\hline & & strong odor & & 229 & 4945 & to die & ma:?it \\
\hline 191 & 3880 & to boil over & fairtir & 230 & 4947 & to surge & ma:2idz \\
\hline 192 & 3882 & to win & fairiz & 231 & 4949 & to surge & ma:?ir \\
\hline 193 & 3890 & $\begin{array}{l}\text { to surpass } \\
\text { to hiccup }\end{array}$ & faitia & 232 & 4968 & $\begin{array}{l}\text { to be rich in } \\
\text { water }\end{array}$ & ma:?ih \\
\hline 194 & 3900 & to utter & fa: 2 ih & 233 & 4974 & to sway & ma:?id \\
\hline 195 & 3902 & to return & faitin & 234 & 4976 & to provide & ma:?ir. \\
\hline 196 & 3905 & to spread a & fa: $:$ ih & 235 & 4977 & to distinguish & ma:?iz \\
\hline & & strong odor & & 236 & 4978 & to strut & ma:?is \\
\hline
\end{tabular}




\begin{tabular}{|c|c|c|c|}
\hline 237 & 4979 & to move away & ma:?it \\
\hline 238 & 4980 & $\begin{array}{l}\text { from } \\
\text { to become } \\
\text { fluid }\end{array}$ & ma: $i \mathrm{j}^{\mathrm{c}}$ \\
\hline 239 & 4990 & $\begin{array}{l}\text { to deviate } \\
\text { from }\end{array}$ & ma:2il \\
\hline 240 & 4996 & $\begin{array}{l}\text { to be rich in } \\
\text { water }\end{array}$ & ma:?ing \\
\hline 241 & 5265 & to burden & $n a-2$ in \\
\hline 242 & 5266 & $\begin{array}{l}\text { to return } \\
\text { to be affected } \\
\text { by } \\
\text { to take place } \\
\text { of }\end{array}$ & na:-2ib \\
\hline 243 & 5269 & to moan & na: 2 ih \\
\hline 244 & 5271 & to illuminate & na-2ir \\
\hline 245 & 5275 & to vacillate & na:-2is \\
\hline 246 & 5276 & to take & na:-3if \\
\hline 247 & 5278 & to resort to & na:-3is \\
\hline 248 & 5279 & $\begin{array}{l}\text { to be } \\
\text { dependent on }\end{array}$ & na:-2it \\
\hline
\end{tabular}

\begin{tabular}{|c|c|c|c|}
\hline 249 & 5281 & to rise & na:2if \\
\hline 250 & 5284 & to get & na:2i1 \\
\hline 251 & 5285 & to sleep & na:Sim \\
\hline 252 & 5291 & $\begin{array}{l}\text { to be } \\
\text { unfortunate }\end{array}$ & na:2ib \\
\hline 253 & 5296 & to line up & na: 2 ir \\
\hline 254 & 5303 & to achieve & na:-2i1 \\
\hline 255 & 5480 & to repent & ha:2id \\
\hline 256 & 5482 & to collapse & hacizis. \\
\hline 257 & 5484 & to tremble & ha:-2if \\
\hline 258 & 5486 & to fear & ha: 2 it \\
\hline 259 & 5492 & to look good & ha:-3in \\
\hline 260 & 5494 & to fear & ha:-2ib \\
\hline 261 & 5496 & to be agitated & ha:Zid3. \\
\hline 262 & 5510 & to break & ha:Zid \\
\hline 263 & 5511 & to be wide & ha: $2 \mathrm{ic}^{\mathrm{c}}$ \\
\hline 264 & 5517 & $\begin{array}{l}\text { to wander } \\
\text { to be thirsty }\end{array}$ & ha: Zim \\
\hline
\end{tabular}

Appendix (C)

Table 7. Finally-Weak APs of the Pattern $\mathrm{C}_{1} \mathrm{a}: \mathrm{C}_{2} \mathrm{iC}_{3}$

\begin{tabular}{|c|c|c|c|c|c|c|c|}
\hline \multirow{5}{*}{ Number } & \multirow{5}{*}{$\begin{array}{l}\text { Dictionary } \\
\text { entry } \\
\text { number }\end{array}$} & \multirow{5}{*}{ Gloss } & \multirow{5}{*}{$\begin{array}{l}\text { Active } \\
\text { participle }\end{array}$} & & \multirow[b]{2}{*}{ ba:kin } \\
\hline & & & & 13 & 713 & to cry & \\
\hline & & & & 14 & 751 & to test & ba-lin \\
\hline & & & & 15 & 751 & to wear off & ba-lin \\
\hline & & & & 16 & 789 & to build & ba:nin \\
\hline 1 & 43 & $\begin{array}{l}\text { to become a } \\
\text { father }\end{array}$ & 2a:bin & 17 & 803 & $\begin{array}{l}\text { to look } \\
\text { beautiful }\end{array}$ & ba:hin \\
\hline 2 & 45 & to refuse & 2a:bin & 18 & 985 & $\begin{array}{l}\text { to follow } \\
\text { to recite }\end{array}$ & ta:lin \\
\hline 3 & 56 & to come & 2a:tin & 19 & 1057 & to bleat & fayin \\
\hline 4 & 83 & to have a & 2a: $x$ in & 20 & 1078 & to bend & Ea:nin \\
\hline & & brother & & 21 & 1110 & to collect & dza:bin \\
\hline 5 & 178 & to comfort & $2 a \cdot \sin$ & 22 & 1111 & to collect & dza:bin \\
\hline 6 & 179 & to heal & 2a:sin & 23 & 1114 & to bow & dza: $\operatorname{lin}$ \\
\hline 7 & 253 & to weaken & 2a:lin & 24 & 1164 & to run & dzarrin \\
\hline 8 & 324 & to slow down & 2a:nin & 25 & 1172 & to recompense & dza:zin \\
\hline 9 & 522 & to appear & ba:din & 26 & 1197 & to harden & dza:fin \\
\hline 10 & 605 & to sharpen & barrin & 27 & 1214 & to rinse & dza:lin \\
\hline 11 & 689 & $\begin{array}{l}\text { to be unjust } \\
\text { to want }\end{array}$ & ba-yin & 28 & 1245 & $\begin{array}{l}\text { to commit a } \\
\text { crime }\end{array}$ & dzainin \\
\hline 12 & 703 & to stay & ba:gin & & & to gather & \\
\hline
\end{tabular}




\begin{tabular}{|c|c|c|c|c|c|c|c|}
\hline & & & & \\
\hline 29 & 1328 & to throw & ha:-in & 58 & 1803 & to call & da-cin \\
\hline 30 & 1329 & to throw & ha: $\theta$ in & 59 & 1840 & to express & da-lin \\
\hline 31 & 1337 & to be wise & ha:dzin & & & one's opinions & \\
\hline 32 & 1337 & to be wise & ha:dzin & 60 & 1856 & to bleed & da:min \\
\hline \multirow[t]{3}{*}{33} & \multirow{3}{*}{1347} & to sing for & ha:din & 61 & & & \\
\hline & & camels & & $\begin{array}{l}01 \\
62\end{array}$ & $\begin{array}{l}1863 \\
1876\end{array}$ & $\begin{array}{l}\text { to get closer } \\
\text { to be }\end{array}$ & $\begin{array}{l}\text { da:ntn } \\
\text { da:hin }\end{array}$ \\
\hline & & to follow & & \multirow{5}{*}{63} & \multirow{5}{*}{1878} & experienced by & da:han \\
\hline $\begin{array}{l}34 \\
35\end{array}$ & $\begin{array}{l}1355 \\
1397\end{array}$ & $\begin{array}{l}\text { to imitate } \\
\text { to sip }\end{array}$ & $\begin{array}{l}\text { ha:din } \\
\text { ha:sin }\end{array}$ & & & to be & da:hin \\
\hline $\begin{array}{l}32 \\
36\end{array}$ & 1404 & to stuff & 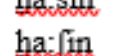 & & & experienced & \\
\hline 37 & 1434 & to give & ha:fin & & & by & \\
\hline & & generously & & & & to be insightful & \\
\hline \multirow[t]{2}{*}{38} & \multirow[t]{2}{*}{1434} & to walk & \multirow{2}{*}{ ha:fin } & 64 & 1958 & to disperse & Qa-rin \\
\hline & & barefoot & & 65 & 1959 & to disperse & Qa-rin \\
\hline 39 & 1446 & to talk & ha:kin & 66 & 1969 & to intensify & da-kin \\
\hline 40 & 1459 & to be sweet & ha:lin & & & & \\
\hline 41 & 1476 & to be hot & ha:min & 67 & 2032 & to increase & raibin \\
\hline \multirow[t]{4}{*}{42} & \multirow[t]{4}{*}{1477} & to protect & \multirow{4}{*}{ ha:min } & 68 & 2032 & to row & ra:bin \\
\hline & & to put someone & & 69 & 2045 & to & ra:lin \\
\hline & & on a diet & & & & commemorate & \\
\hline & & to be hot & & 70 & 2046 & to & ra:lin \\
\hline \multirow[t]{3}{*}{43} & \multirow[t]{3}{*}{1493} & to feel & \multirow[t]{3}{*}{ ha:nin } & & & commemorate & \\
\hline & & compassion & & 71 & 2059 & to hope & raidzin \\
\hline & & for & & 72 & 2066 & to cause to & ra:hin \\
\hline 44 & 1494 & to bend & ha:nin & & & revolve & \\
\hline \multirow{2}{*}{45} & \multirow{2}{*}{1553} & to be & \multirow{2}{*}{ xa:bin } & 73 & 2067 & to grind & ra:hin \\
\hline & & extinguished & & 74 & 2104 & to moor & rasing \\
\hline \multirow{2}{*}{46} & \multirow{2}{*}{1624} & \multirow{2}{*}{ to fear } & \multirow{2}{*}{ xa:-ist. } & 75 & 2112 & to bribe & $\mathrm{ra}: \sqrt{\mathrm{in}}$ \\
\hline & & & & 76 & 2124 & to be satisfied & radin \\
\hline 47 & 1632 & to be castrated & $x a \cdot \sin$ & & & & \\
\hline 48 & 1650 & to walk & xatin & 77 & 2140 & to herd sheep & racin \\
\hline 49 & 1657 & to be hidden & xa:fin & & & to care for & \\
\hline 50 & 1658 & to hide & xa-fin & 78 & 2146 & to froth & ravin \\
\hline 51 & 1658 & to be hidden & xa:fin & 79 & & to grunt & \\
\hline & & & & 79 & 2160 & to get married & ra:fin \\
\hline 52 & 1673 & to be empty & xadina & 80 & 2171 & to recite Quran & raigin \\
\hline & & to be devoted & & & & over someone & \\
\hline & & to & & & & $\begin{array}{l}\text { for healing and } \\
\text { protection }\end{array}$ & \\
\hline 53 & 1696 & to use impolite & xa:nin & 81 & 2171 & to advance & ra:ain \\
\hline & & & & 82 & 2196 & to throw & ra:min \\
\hline 54 & 1697 & $\begin{array}{l}\text { to use impolite } \\
\text { language }\end{array}$ & xa:nin & 83 & 2206 & $\begin{array}{l}\text { to look } \\
\text { forward to }\end{array}$ & rainin \\
\hline 55 & 1747 & to become & da:dzin & 84 & 2274 & to push gently & za:dzin. \\
\hline & & dark & cescrant & 85 & 2297 & to mock & zarrin \\
\hline 56 & 1753 & to flatten & da:hin & 86 & 2325 & to increase & za:kin \\
\hline 57 & 1754 & to flatten & da:hin & 87 & 2326 & to increase & za:kin \\
\hline & & & & 88 & 2365 & to fornicate & za:nin \\
\hline
\end{tabular}




\begin{tabular}{|c|c|c|c|c|c|c|c|}
\hline & & & & \\
\hline 89 & 2369 & to be arrogant & za:hin & 126 & 3136 & to increase & da:fin \\
\hline 90 & 2434 & to imprison & sa:bin & 127 & 3184 & to flatten & ta:hin \\
\hline \multirow[t]{2}{*}{91} & 2454 & to be calm & sa:dzin & 128 & 3208 & to be despotic & taidin \\
\hline & & to cover & & 129 & 3217 & to float & ta:fin \\
\hline 92 & 2466 & to dredge & sa:hin & 130 & 3030 & to paint & ta:lin \\
\hline 93 & 2466 & to dredge & sa:hin & 131 & 3040 & to silt & tatmin \\
\hline \multirow[t]{2}{*}{94} & 2474 & to become & saxin & 132 & 3248 & to cook & ta:hin \\
\hline & & generous & & 133 & 3249 & to cook & ta-hin \\
\hline 95 & 2475 & $\begin{array}{l}\text { to become } \\
\text { generous }\end{array}$ & saxin & 134 & 3308 & to be arrogant & catin \\
\hline \multirow[t]{2}{*}{96} & 2511 & & sa:rin & & & to be very old & \\
\hline & & to spread & & 135 & 3311 & to cause & Saitin \\
\hline 97 & 2520 & to assail & sa:tin & & & mischief & \\
\hline 98 & 2527 & $\begin{array}{l}\text { to strive } \\
\text { to betray }\end{array}$ & sa: in & 136 & 3312 & $\begin{array}{l}\text { to cause } \\
\text { mischief }\end{array}$ & saitin. \\
\hline 99 & 2545 & to disperse & sa:fin & 137 & 3330 & to run & Sadin \\
\hline \multirow[t]{3}{*}{100} & 2554 & to give & sa:qin & & & to be unjust & \\
\hline & & someone a & & 138 & 3355 & to befall & Sartin \\
\hline & & drink & & 139 & 3356 & to get nacked & Sarrin \\
\hline 101 & 2590 & to forget & sa:lin & 140 & 3367 & to be ascribed & arzin. \\
\hline \multirow[t]{2}{*}{102} & 2590 & to cause to & sa:lin & & & to & \\
\hline & & forget & & 141 & 3368 & to be ascribed & azizin \\
\hline 103 & 2618 & to rise up & sa:min & & & to & \\
\hline 104 & 2652 & to lighten & sa:nin & 142 & 3395 & to disobey & casin \\
\hline 105 & 2658 & to forget & sa:hin & 143 & 3419 & to be removed & aifin \\
\hline 106 & 2760 & to rain & fatin & & & to forgive & \\
\hline 107 & 2766 & to become sad & fa:dzin & 144 & 3449 & to be high & a:lin \\
\hline 108 & 2788 & to sing & faidin & 145 & 3451 & to rise & cailin \\
\hline 109 & 2792 & to smell good & fardin & 146 & 3482 & to take by & cainin \\
\hline 110 & 2813 & to buy & farrin & & & force & \\
\hline 111 & 2858 & to heal & fa:fin & & & to submit to & \\
\hline 112 & 2866 & $\begin{array}{l}\text { to be } \\
\text { distressed }\end{array}$ & Jaigin & 147 & 3484 & $\begin{array}{l}\text { to pay } \\
\text { attention to }\end{array}$ & Sanin \\
\hline 113 & 2873 & to complain & fa.kin & & & to be & \\
\hline 114 & 2875 & to complain & faikin & & & exhausted & \\
\hline 115 & 2969 & to long for & sa:bin & 148 & 3530 & to feel sick & ya: $\theta$ in \\
\hline 116 & 2970 & to act boyishly & sa:bin & 149 & 3531 & to feel sick & ya:-in \\
\hline 117 & 2977 & to wake up & sa:hin & 150 & 3531 & to feel sick & ya: $\theta$ in \\
\hline 118 & 2978 & to wake up & sa:hin & 151 & 3531 & to talk a lot & ya:-in \\
\hline 119 & 2991 & to get thirsty & sa:din & 152 & 3538 & to leave at & va:din \\
\hline 120 & 3010 & to decline from & saivin & & & lunch time & \\
\hline 121 & 3011 & to decline from & saivin & & & to become & \\
\hline 122 & 3020 & to be pure & sa:fin & 153 & 3540 & to feed & ya-ðin \\
\hline 123 & 3039 & to be tortured & sa:lin & 154 & 3559 & to glue & yacrin \\
\hline 124 & 3113 & to be in the & da:hin & 155 & 3565 & to invade & ya:zin \\
\hline & & forenoon & & 156 & 3571 & to darken & va:-din \\
\hline 125 & 3126 & to fight hard & daring & & & to come upon & \\
\hline
\end{tabular}




\begin{tabular}{|c|c|c|c|c|c|c|c|}
\hline \multirow[b]{2}{*}{157} & \multirow[b]{2}{*}{3590} & \multirow[b]{2}{*}{ to sleep } & \multirow[b]{2}{*}{ ya:fin } & \\
\hline & & & & 198 & 4838 & to walk & ma: $\int$ in \\
\hline & 3591 & to sleep & ya:fin & 199 & 4848 & to go away & ma:din \\
\hline & 3603 & to become & ya:-lin & & & to sign & \\
\hline & & expensive & & 200 & 4888 & to whistle & ma:kin \\
\hline & & to be excessive & & 201 & 4927 & to test & ma:nin \\
\hline & 3604 & to boil & ya:-lin & 202 & 4928 & to test & ma:nin \\
\hline & 3622 & to become rich & ya:nin & 203 & 4999 & to be distant & na:? in \\
\hline & 3714 & to sacrifice & fa: din & 204 & 5026 & to be & na:bin \\
\hline & 3761 & to lie & farrin & & & inconsistent & \\
\hline & 3779 & to fart & fasisto & & & with & \\
\hline & 3787 & to spread & fa: in & 205 & 5055 & to make a & na:dzin \\
\hline & 3797 & to be empty & fa: $\operatorname{din}$ & & & secret & \\
\hline & 3845 & to delouse & failin & & & conversation & \\
\hline & 3848 & to delouse & fálin & & & to survive & \\
\hline & 3863 & to perish & fasnin & 206 & 5066 & to head for & na:hin \\
\hline & 3945 & to bend & ga:bin & 207 & 5076 & to be proud & naxin \\
\hline & 3970 & to have motes & ga: & 208 & 5103 & to need & na:zin \\
\hline & & in the eye & & 209 & 5116 & to leave & na:sin \\
\hline & 4007 & to follow & garrin & 210 & 5117 & to forget & na:sin \\
\hline & 4008 & to host & garrin & 211 & 5133 & to get drunk & na: $\sqrt{\text { in }}$ \\
\hline & 4021 & to be harsh & ga $\sin$ & 212 & 5142 & to catch from & na: $\sin$ \\
\hline & 4042 & to become & ga: $\sin$ & & & the forelock & \\
\hline & & distant & & 213 & 5150 & to undress & na:din \\
\hline & 4046 & to judge & ga:din & 214 & 5171 & to make a & na -cint $^{-1}$ \\
\hline & 4058 & to miagul & ga-tin & & & sound & \\
\hline & 4073 & to follow & ga:fin & 215 & 5172 & to announce & na-cint \\
\hline & 4089 & to fry & ga:lin & & & the death of & \\
\hline & 4089 & to hate & ga:-lin & & & someone & \\
\hline & 4121 & to become red & ga:nin & 216 & 5183 & to babble & naxyin \\
\hline & $82 \quad 4224$ & to fall & ka:bin & 217 & 5200 & to deny & na:fin \\
\hline 183 & 4342 & to sheathe & ka:sin & 218 & 5235 & to defeat & na:kin \\
\hline 184 & 4372 & to have enough & ka:fin & 219 & 5248 & to grow & na:min \\
\hline 185 & 4428 & to call & ka:nin & 220 & 5250 & to increase & na:min \\
\hline 186 & 4428 & to imply & ka:nin & 221 & 5264 & to prevent & na:hin \\
\hline 187 & 4544 & to peel & la:hin & 222 & 5350 & to rise & ha:bin \\
\hline 188 & 4570 & to blaze & la: $\delta$ in & 223 & 5366 & to satirize & ha:dzin \\
\hline 189 & 4585 & to smatter & lasidin & 224 & 5379 & to guide & ha:din \\
\hline 190 & 4585 & to smatter & laving & 225 & 5383 & to ramble & ha: in \\
\hline 191 & 4603 & to encounter & la:gin & 226 & 5399 & to hit with a & ha-rin \\
\hline \multirow[t]{2}{*}{192} & 4634 & to be amused & la:hin & & & baton & \\
\hline & & to be distracted & & 227 & 5402 & to wear out & hasrin \\
\hline 193 & 4634 & to divert from & la:hin & & & clothes & \\
\hline 194 & 4754 & to remove & ma:hin & 228 & 5429 & to be mistaken & ha:fin \\
\hline 195 & 4756 & to erase & ma:hin & 229 & 5464 & to wander & hasming \\
\hline 196 & 4769 & to stab & ma:din & & & & \\
\hline 197 & 4808 & $\begin{array}{l}\text { to be } \\
\text { ungrateful }\end{array}$ & ma:rin & & & & \\
\hline
\end{tabular}


Appendix (D)

Table 8. Doubly-weak APs of the Pattern $\mathrm{C}_{1} \mathrm{a}: \mathrm{C}_{2} \mathrm{iC}_{3}$

\begin{tabular}{|c|c|c|c|}
\hline Number & $\begin{array}{l}\text { Dictionary } \\
\text { entry } \\
\text { number }\end{array}$ & Gloss & $\begin{array}{l}\text { Active } \\
\text { participle }\end{array}$ \\
\hline 1 & 372 & $\begin{array}{l}\text { to } \\
\text { accommodate }\end{array}$ & 3a:win \\
\hline 2 & 1083 & to settle & Eawin \\
\hline 3 & 1709 & to be empty & xa-win \\
\hline 4 & 1514 & to include & hawin. \\
\hline 5 & 1901 & $\begin{array}{l}\text { to make loud } \\
\text { noise }\end{array}$ & dawin \\
\hline 6 & 1990 & to wither & dawin \\
\hline 7 & 2241 & $\begin{array}{l}\text { to quench } \\
\text { to narrate }\end{array}$ & raiving \\
\hline 8 & 2385 & to dismiss & za:xin \\
\hline 9 & 2932 & to barbeque & Saixida. \\
\hline 10 & 3155 & to join & dawin \\
\hline 11 & 3155 & to be weak & dawin \\
\hline 12 & 3262 & to fold & taiwin \\
\hline 13 & 3503 & to bark & Saivin \\
\hline 14 & 3632 & $\begin{array}{l}\text { to deviate } \\
\text { from what is } \\
\text { right }\end{array}$ & yawin \\
\hline
\end{tabular}

\begin{tabular}{|c|c|c|c|}
\hline 15 & 4477 & to burn & kawin \\
\hline 16 & 4664 & to bend & lawwin \\
\hline 17 & 5289 & to depart & nawin \\
\hline 18 & 5490 & $\begin{array}{l}\text { to intend } \\
\text { to fall } \\
\text { to perish }\end{array}$ & hawin \\
\hline 19 & 5564 & to inspire & wa:hin \\
\hline 20 & 5574 & $\begin{array}{l}\text { to give blood } \\
\text { money }\end{array}$ & wa:din \\
\hline 21 & 5615 & $\begin{array}{l}\text { to adorn } \\
\text { to inform } \\
\text { against }\end{array}$ & wa: in \\
\hline 22 & 5646 & to realize & wa-cin \\
\hline 23 & 5655 & $\begin{array}{l}\text { to fulfill } \\
\text { to increase }\end{array}$ & wa fin \\
\hline 24 & 5665 & to protect & wa:gin \\
\hline 25 & 5687 & $\begin{array}{l}\text { to be close } \\
\text { to rule }\end{array}$ & wa:lin \\
\hline 26 & 5692 & to abandon & wa:nin \\
\hline 27 & 5701 & to be weak & wathin \\
\hline
\end{tabular}

\section{Modern standart Arapça'da üç ünsüzden oluşan fiillerden zayıf aktif sıfat-fiil türetilmesinin otomatik segment analizi}

$\ddot{O} \mathbf{z}$

$\mathrm{Bu}$ çalışma, otosegmental fonolojinin X-slot modelinde triconsonantal eksik fiillerden zayıf aktif sıfat fiil türetilmesini analiz etmeyi amaçlamaktadır. Araştırmanın ilk aşaması, sağlam köklü bir sözlükten korpus oluşturmayı içerir. Korpus, başta, ortada, sonda ve iki kat zayıf sıfat fiil olarak kategorize edilen 620 sıfat fiil içerir. Analiz, düzensiz yüzey temsillerine sahip olmalarına rağmen, zayıf sıfat fiillerin temeldeki temsillerinin güçlü emsallerininkilerle paralel olduğunu ortaya koymaktadır. Bu sıfat fiillerin yüzey düzensizlikleri, kaymaların çeşitli fonolojik kurallara duyarlı olmalarına neden olan doğal kararsızlığına atfedilebilir. Bu fonolojik kurallara, bu yaklaşımda farklı katmanlardaki öğelerin sahip olduğu özerklik nedeniyle, otomatik segmental fonolojide doğru ve basit temsiller verilmiştir.

Anahtar sözcükler: Otosegmental fonoloji; MSA; korpus çalışması; zayıf gövdeler; sıfat fiil 


\section{AUTHOR BIODATA}

Eman Awni Ali is a lecturer at the University of Jordan. She received her BA in English Language and Literature from Al-Balqa'a Applied University in 2010 and her PhD in Linguistics from the University of Jordan in 2020. Ali's research interests include the areas of phonology and phonetics, language acquisition and sociolinguistics. ORCID: https://orcid.org/0000-0001-5652-4813

Radwan Salim Mahadin is a Professor of linguistics at the University of Jordan, Amman, Jordan. He received his BA in English Language and Literature from the University of Jordan in 1976 and his PhD in Linguistics from the University of Pennsylvania in 1982. Mahadin's research interests include, but not limited to, the areas of phonology and phonetics, discourse analysis, semantics, pragmatics and historical linguistics. 